Chandler Benjamin M. P. (Orcid ID: 0000-0003-1532-9696)

Lovell Harold (Orcid ID: 0000-0002-9435-3178)

Roberts David H. (Orcid ID: 0000-0002-5976-8423)

Schaefer Martin (Orcid ID: 0000-0003-4905-1354)

\title{
Sub-annual moraine formation at an active temperate Icelandic glacier
}

Benjamin M. P. Chandler ${ }^{1,2} * \mid$ Samuel J. P. Chandler ${ }^{1}$ | David J. A. Evans ${ }^{3} \mid$ Marek W.

Ewertowski ${ }^{4}$ | Harold Lovell ${ }^{1}$ | David H. Roberts ${ }^{3} \mid$ Martin Schaefer $^{1} \mid$ Aleksandra M. Tomczyk ${ }^{4}$

${ }^{1}$ School of the Environment, Geography and Geosciences, University of Portsmouth,

Portsmouth, UK

${ }^{2}$ Department of Physical Geography, Stockholm University, Stockholm, Sweden

${ }^{3}$ Department of Geography, Durham University, Durham, UK

${ }^{4}$ Faculty of Geographical and Geological Sciences, Adam Mickiewicz University, Poznań,

Poland

*Correspondence to: Benjamin M. P. Chandler. Department of Physical Geography, Stockholm University, SE 106-91 Stockholm, Sweden. (Email: benjamin.chandler@ natgeo.su.se)

This article has been accepted for publication and undergone full peer review but has not been through the copyediting, typesetting, pagination and proofreading process which may lead to differences between this version and the Version of Record. Please cite this article as doi: $10.1002 /$ esp.4835

This article is protected by copyright. All rights reserved. 
ABSTRACT. This paper presents detailed geomorphological and sedimentological investigations of small recessional moraines at Fjallsjökull, an active temperate outlet of Öræfajökull, southeast Iceland. The moraines are characterised by striking sawtooth or hairpin planforms, which are locally superimposed, giving rise to a complex spatial pattern. We recognise two distinct populations of moraines, namely a group of relatively prominent moraine ridges (mean height $\sim 1.2 \mathrm{~m}$ ) and a group of comparatively low-relief moraines (mean height $\sim 0.4 \mathrm{~m}$ ). These two groups often occur in sets/systems, comprising one pronounced outer ridge and several inset smaller moraines. Using a representative subsample of the moraines, we establish that they form by either (i) submarginal deformation and squeezing of subglacial till or (ii) pushing of extruded tills. Locally, proglacial (glaciofluvial) sediments are also incorporated within the moraines during pushing. For the first time, to our knowledge, we demonstrate categorically that these moraines formed sub-annually using repeat uncrewed aerial vehicle (UAV) imagery. We present a conceptual model for subannual moraine formation at Fjallsjökull that proposes the sawtooth moraine sequence comprises (i) sets of small squeeze moraines formed during melt-driven squeeze events and (ii) larger push moraines formed during winter re-advances. We suggest the development of this process-form regime is linked to a combination of elevated temperatures, high surface meltwater fluxes to the bed, and emerging basal topography (a depositional overdeepening). These factors result in highly saturated subglacial sediments and high porewater pressures, which induces submarginal deformation and ice-marginal squeezing during the melt season. Strong glacier recession during the summer, driven by elevated temperatures, allows several squeeze moraines to be emplaced. This process-form regime may be characteristic of active temperate glaciers receding into overdeepenings during phases of elevated temperatures, especially where their englacial drainage systems allow efficient transfer of surface meltwater to the glacier bed near the snout margin. 
Keywords: Sub-annual moraines, ice-marginal moraines, glacier submarginal processes, subglacial deforming layer, active temperate glacier, Fjallsjökull, Iceland

\section{1 | INTRODUCTION}

Moraines formed by seasonally-driven processes at a glacier margin are important terrestrial archives, since the processes contributing to their formation can be clearly linked to glaciological and climatic conditions active in a given year (e.g. Bradwell, 2004a; Beedle et al., 2009; Lukas, 2012; Chandler et al., 2016a). In some cases, ice-marginal moraines are formed annually by short-lived seasonal (winter) re-advances during periods of overall icemargin retreat. Consecutively younger, inset annual moraines can form where glacier retreat during the summer exceeds successive winter re-advances over a number of years (e.g. Boulton, 1986; Lukas, 2012; Bradwell et al., 2013; Reinardy et al., 2013). Annual moraines have been reported by numerous researchers (e.g. Thórarinsson, 1967; Worsley, 1974; Karlén and Denton, 1975; Gordon and Timmis, 1992; Schomacker et al., 2012; Hiemstra et al., 2015; Luckman, 2017) but detailed insights into linkages between annual moraine-forming processes and glaciological, environmental and other boundary conditions remain relatively limited (e.g. Sharp, 1984; Boulton, 1986; Krüger, 1995; Evans and Hiemstra, 2005; Lukas, 2012; Reinardy et al., 2013; Chandler et al., 2016a; Wyshnytzky, 2017). Crucially, a detailed understanding of the processes contributing to seasonal/annual moraine formation, their spatio-temporal variations and the controls thereon (e.g. climatic, glaciological and topographic) is required to unravel the complexity of moraine formation in general. By obtaining detailed insights into the dynamic nature of moraine genesis in contemporary glacial environments, process-form models grounded on modern process observations (modern analogues) can be developed for moraines formed at the margins of palaeo-ice 
masses during the Quaternary. The sedimentological end products (ice-marginal moraines) in ancient glacial environments can thus then be used to reconstruct past glacier dynamics (e.g. Ham and Attig, 2001; Sutherland et al., 2019).

Annual moraines are particularly prevalent in Iceland and long sequences of (presumed) annual moraines are ubiquitous on the low-lying forelands of the maritime outlets of Öræfajökull and Vatnajökull, southeast Iceland (e.g. Thórarinsson, 1967; Price, 1970; Sharp, 1984; Boulton, 1986; Evans and Twigg, 2002; Evans and Hiemstra, 2005; Chandler et al., 2016a, b, c; Evans et al., 2016a, 2017, 2019a). With their distinctive, intricate 'sawtooth' or crenulated planforms, these annual moraine sequences are spectacular phenomena and a characteristic signature of the active temperate glacial landsystem (cf. Evans and Twigg, 2002; Evans, 2003). Previous work has established that annual moraines in these settings are manifestations of the thickening of the subglacial deforming layer and production of submarginal till wedges, predominantly by seasonal cycles of squeezing and pushing (cf. Price, 1970; Sharp, 1984; Evans and Hiemstra, 2005; Chandler et al., 2016a; Evans, 2018). Operation of these coupled processes at heavily-crevassed glacier margins gives rise to the distinctive planforms: extrusion of saturated till through radial crevasses (or pecten) and subsequent pushing result in moraines that reflect the morphology of the glacier margin (see Chandler et al., 2016a, and references therein). While seasonal cycles of these processes have been linked to the formation of single push/squeeze moraines on an annual basis, Chandler et al. (2016a) recently reported the formation of sub-annual moraines (i.e. multiple moraine ridges per year) at Skálafellsjökull; decoupling of the squeeze-push mechanism was suggested to be responsible for the formation of these ridge systems. However, further research is necessary to (i) establish the prevalence of sub-annual moraines at active temperate glaciers, (ii) understand the processes contributing to the formation of these small 
moraines, and (iii) elucidate controls on the moraine-forming processes and the frequency of moraine formation.

In this study, we examine the formation of small recessional moraines (hereafter 'minor moraines') at the southern margin of Fjallsjökull, southeast Iceland (Fig. 1). The aims of this paper are threefold: (i) to determine processes contributing to the formation of minor moraines at Fjallsjökull based on sedimentological data from a representative selection of moraines; (ii) to establish the frequency of moraine formation using remotely-sensed data, including a time series of images (2016-2019) captured during repeat uncrewed aerial vehicle (UAV) surveys; and (iii) to assess potential controls on the moraine-forming processes and frequency of moraine formation.

\section{2 | STUDY AREA}

Fjallsjökull $\left(64^{\circ} 01^{\prime} \mathrm{N}, 16^{\circ} 25^{\prime} \mathrm{W}\right)$ is an active temperate outlet of Öræfajökull, situated in the southern part of Vatnajökull, southeast Iceland (Fig. 1). The outlet glacier and its neighbour, Hrútárjökull, drain the eastern side of Öræfajökull; Fjallsjökull flows eastwards from its highelevation ice divide at $2030 \mathrm{~m}$ a.s.1., descending steeply via an icefall between Ærfjall and Breiðmerkurfjall, before flowing out onto a low elevation foreland (10-30 m a.s.1.). At its Little Ice Age (LIA) maximum, the outlet splayed out to form a piedmont lobe and was coalescent with Breiðamerkurjökull (to the northeast) (see Thórarinsson, 1943; Evans and Twigg, 2002; Evans et al., 2009, 2019b). A maximum lichenometric age of 1727 CE was proposed by Bradwell (2004b) for the outermost Fjallsjökull moraines, whereas Evans et al. (2019b) derived an age of $1890 \mathrm{CE}$ for the outermost Breiðamerkurjökull moraines. The latter is more consistent with historical archives that suggest Fjallsjökull reached its LIA 
maximum in $1870 \mathrm{CE}$ before re-advancing to the same position in $1894 \mathrm{CE}$ (cf. Thórarinsson, 1943).

Westwards retreat of Fjallsjökull from its LIA limit during the 20th and 21st centuries (see Fig. 1) has revealed a substantial overdeepening, and much of the glacier margin now terminates in the proglacial lake, Fjallsárlón (see also Magnússon et al., 2012). Recent research has shown that the basal topography and proglacial lake expansion has led to the development of an increasingly spatially complex ice flow regime over the past $\sim 20$ years, characterised by localised zones of higher flow velocity ('fast flow' corridors) that have propagated towards the calving front (Dell et al., 2019). In this paper, we focus on moraineforming processes and associated glacier dynamics at the southern margin. At the time of our investigations, this sector was land terminating and producing minor moraines on the distal slopes of a large ice-contact fan/ramp that forms the local adverse slope of a depositional overdeepening (Evans et al. 2018b).

Regular measurements of ice-front fluctuations have been conducted at the southern Fjallsjökull margin since 1934 (Fig. 2; e.g. Eypórsson, 1935, 1963, Sigurðsson et al., 2007). These measurements reveal rapid ice-margin retreat between 1935 and $1941\left(\sim 90 \mathrm{~m} \mathrm{a}^{-1}\right)$, before more gradual retreat until the 1960s (1942-1959: 9 $\mathrm{m} \mathrm{a}^{-1}$ ). A brief phase of rapid retreat followed between 1960 and $1963\left(\sim 46 \mathrm{~m} \mathrm{a}^{-1}\right)$. The ice-front record was then punctuated by short-lived advances in the 1960s (1964-1966: 21 $\left.\mathrm{m} \mathrm{a}^{-1}\right), 1970 \mathrm{~s}(1974-1976$ : 26 $\left.\mathrm{m} \mathrm{a}^{-1}\right)$, 1980s (1982-1983: 16 $\left.\mathrm{m} \mathrm{a}^{-1}\right)$, and 1990s (1995-1996: 19 $\mathrm{m} \mathrm{a}^{-1}$ ). Fjallsjökull experienced sustained retreat at its southern margin from the 1990s until the last available measurement in $2014\left(\sim 35 \mathrm{~m} \mathrm{a}^{-1}\right)$. Aerial photographs captured sporadically since 1945 indicate that minor moraines were formed at Fjallsjökull during the retreat periods recorded 
by the ice-front measurements (cf. Price, 1970), and at a particularly high frequency since the 1990s re-advance.

\section{3 | DATASETS AND METHODS \\ 3.1 Geospatial datasets}

For the purposes of mapping the minor moraines at Fjallsjökull, and to provide bracketing positions for assessing recent moraine formation frequency, we acquired a range of remotelysensed data: (i) an airborne LiDAR dataset collected in 2011 and 2012 by the Icelandic Meteorological Office and the Institute of Earth Sciences, University of Iceland (Jóhannesson et al., 2013); (ii) pansharpened, multi-spectral satellite imagery ( $0.5 \mathrm{~m}$ per pixel) captured by the WorldView-2 satellite in September 2014; and (iii) a time series of UAV-captured imagery, collected during surveys of the southern glacier margin in 2016, 2017, 2018 and 2019. Below, we provide an overview of the UAV surveying and data processing methods employed in this study. Detailed descriptions of the methods and parameters, as well as precision analysis of our UAV-derived models, are available as Supporting Information.

\subsection{UAV surveying and data processing}

Repeat UAV surveys were conducted in 2016-2019 (see Fig. 1) with the specific aim of capturing high-resolution aerial imagery to (a) map minor moraines at the southern glacier margin in detail and (b) establish the frequency of minor moraine formation in recent years. Our UAV surveying and data processing approach followed the operational framework outlined by Ewertowski et al. (2019). We conducted UAV surveys using small, lightweight, 
consumer-grade quadcopters (DJI Phantom 3 and 4) over an area of up to $\sim 0.5 \mathrm{~km}^{2}$. Each survey was planned to capture images with high overlap and small ground sampled distances (GSDs), which would enable high-precision and high-resolution models to be produced (see Supporting Information, for further details). The surveys yielded imagery with GSDs of $2.17-3.28 \mathrm{~cm}$ per pixel (Table 1).

The UAV-captured imagery was processed in Agisoft Metashape Professional Edition 1.5.3. This photogrammetric software combines Structure-from-Motion (SfM) and Multi View Stereo (MVS) to extract 3D point clouds and orthomosaics from sets of overlapping 2D imagery through automated processes (see Westoby et al., 2012; Ryan et al., 2015). We processed the UAV imagery using a semi-automated Python script (https://github.com/gisportsmouth/PhotoScanAutomation-Script) to minimise user input to setting key parameters and manually identifying ground control points (GCPs). As part of the semi-automated process, gradual selection was applied to remove any outliers and highly erroneous tie points from the models. An iterative process was implemented with the aim of removing $80 \%$ of the tie points, thereby improving the quality of the final models (see Supporting Information, for further details).

Positional ground control for the UAV surveys was established in 2019 by surveying artificial targets using a Topcon HiPer V GNSS in post-processing kinematic (PPK) mode (see Supporting Information). The GNSS data were post-processed using RINEX data from the IceCORS network (National Land Survey of Iceland: https://www.lmi.is/en/icecorsnetwork/). The post-processed data were exported in WGS 1984 / UTM Zone 28N (EPSG: 32628), and then orthometric heights were calculated using the Coordinate Conversion and Datum Transformation in Iceland tool (cocodati: http://sandmerki.lmi.is/cocodati/). 
The exterior orientation of the 2019 UAV model was established using 31 GCPs, while a further 22 points were used as independent, external checkpoints. For the 2016, 2017 and 2018 UAV models, positional information was established using GCPs (>19 control points; $>9$ check points) generated from the 2019 UAV orthophoto, i.e. the 2016, 2017 and 2018 were georeferenced to the 2019 model (see Supporting Information).

The SfM processing yielded models with low total internal $(0.05-0.14 \mathrm{~m})$ and external $(0.06-$ $0.17 \mathrm{~m})$ RMSEs, as well as low standard deviations of error $(0.02-0.08 \mathrm{~m})$ (Table 1). Analysis of the spatial variability of precision in our SfM-derived models, using the Monte Carlo approach of James et al. (2017b), demonstrated that the models were of high precision and high quality in terms of image network geometry (see Supporting Information). Additionally, assessments of doming deformation in the models indicated that there was no doming distortion in the models. We used our UAV-derived models to generate orthophotos with GSDs of 2.22-3.36 cm per pixel and DEMs with GSDs of 4.34-6.56 cm per pixel.

\subsection{Geomorphological mapping}

Geomorphological mapping of minor moraines on the Fjallsjökull foreland, along with associated glacial landforms and surficial units, was undertaken following mapping protocols outlined by Chandler et al. (2018). The mapping combined the interpretation of remotelysensed data and extensive field checking. We used Digital Elevation Models (DEMs) derived from the LiDAR point cloud data to produce a glacial geomorphological map of the entire Fjallsjökull foreland. A DEM derived from the 2019 UAV-captured imagery was used for more detailed, high-resolution and up-to-date mapping of a minor moraine sequence formed at the southern margin during the past $\sim 15$ years. In the case of the LiDAR data, DEMs with 
pixel sizes of $1 \mathrm{~m}$ and $2 \mathrm{~m}$ were interpolated from the raw point clouds, which have horizontal and vertical errors of $<0.5 \mathrm{~m}$; the DEMs were reprojected from ISN 2004 / Lambert 2004 (ESPG: 5327) to the UTM Zone 28 N (ESPG: 32628) reference system for mapping.

Mapping was performed digitally (i.e. through on-screen vectorisation) in ESRI ArcMap. Historical aerial photographs (1945, 1965, 1982 and 1998) obtained from Landmælingar Íslands (the National Land Survey of Iceland) were consulted during the mapping, which was helpful in identifying areas of ice-cored terrain. Interpretation of remotely-sensed data was conducted both before and after fieldwork (cf. Chandler et al., 2018). Glacial landforms and surficial geological units were mapped using the colour-coded scheme established at other Icelandic glacier forelands (Fig. 3; e.g. Evans and Twigg, 2002; Evans et al., 2016a, 2017).

\subsection{Sedimentological analysis}

Exposures were created manually through moraines using a trenching tool to enable sedimentological analysis. Annotated, measured drawings of the cleaned sections were produced on square millimetre paper, following established protocols (e.g. Lukas, 2005, 2012; Reinardy et al., 2013; Chandler et al., 2016a). To ensure maximum planimetric accuracy of the final section logs, photomosaics were also produced for each exposure and the field logs were later transferred and vectorised in Adobe Illustrator. Following standard procedures and criteria, individual sedimentary units were identified based on their physical properties, namely grain size, sorting, compaction, sedimentary structures, bed contacts and unit geometry (Evans and Benn, 2004). A lithofacies code, modified from Eyles et al. (1983) and Benn and Evans (2010), was employed for clear, effective and rapid description of the 
sedimentary logs (Fig. 4). Clast shape and roundness were also analysed for each moraine following established methods, with $\mathrm{C}_{40}, \mathrm{RA}, \mathrm{RWR}$ and average roundness (AvR) indices calculated for each sample using a modified version of TriPlot (see Benn and Ballantyne, 1993, 1994; Graham and Midgley, 2000; Spedding and Evans, 2002; Lukas et al., 2013). In this study, AvR was calculated using the scale $\mathrm{VA}=0$ to $\mathrm{WR}=5$, rather than the scale (VA = 1 to WR =6) employed by Spedding and Evans (2002), in order to facilitate direct comparisons with more recent studies (e.g. Evans, 2010; Evans et al., 2018).

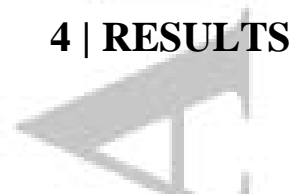

\subsection{Moraine distribution and geomorphology}

Geomorphological mapping reveals an abundance of moraine ridges distributed across the Fjallsjökull foreland (Figs. 5 and 6; cf. Evans et al., 2009). In the outer, eastern-southeastern part of the foreland (areas A-C; Fig. 5), the moraine ridges are arranged as discontinuous, arcuate chains that reach several hundreds of metres in length. These arcuate chains consist of ridge fragments that are $\sim 5-185 \mathrm{~m}$ long (average $\sim 40 \mathrm{~m}$ ). Between the individual moraine chains, fluted/drumlinised, low-amplitude push moraines (overridden moraines) are found, along with sets of flutings (Fig. 5). Individual minor moraines in the outer part of the foreland are 1-5 m high and 15-40 m wide, and they display gently indented/crenulated planforms.

More complex, 'sawtooth' or crenulated planforms are evident in two moraine fields in the central (area D) and northern (area E) parts of the foreland (Fig. 5). These suites of moraines occur atop large mounds that attain maximum heights of $32 \mathrm{~m}$ and $41 \mathrm{~m}$. Minor moraines in areas $\mathrm{D}$ and $\mathrm{E}$ are typically $\sim 0.5-1 \mathrm{~m}$ high and $\sim 4-10 \mathrm{~m}$ wide; they form densely-spaced, 
crenulated chains of moraines that extend for up to $\sim 700 \mathrm{~m}$, with moraine fragments ranging in length from $~ 5-335 \mathrm{~m}$ (Fig. 5). Crest-to-crest spacings between individual chains of moraines vary between $\sim 5 \mathrm{~m}$ and $60 \mathrm{~m}$. Moraines in area $\mathrm{D}$ have previously been subject to sedimentological analysis by Price (1970).

Closely spaced moraine ridges also occur in the southern part of the foreland (area F; Fig. 5), especially on the proximal slope of a large moraine ridge that reaches up to $\sim 90 \mathrm{~m}$ in height (cf. Price, 1970; Rose et al., 1997). Chains of moraines in this area are more fragmentary than the areas described above, with moraine fragments usually having lengths of $\sim 5-50 \mathrm{~m}$ (average: $\sim 25 \mathrm{~m}$ ); however, individual moraines can be connected to form chains that extend for $>1 \mathrm{~km}$. The moraines exhibit similar morphological characteristics to the minor moraines elsewhere on the Fjallsjökull foreland, typically attaining heights of $\sim 0.5-2 \mathrm{~m}$ and widths of $\sim 4-10 \mathrm{~m}$.

The most complex and densely spaced minor moraines occur near the present-day (2019), southern Fjallsjökull margin (Figs. 5 and 6). These moraines are the focus for the remainder of this contribution and are thus described in more detail here. The assemblage of minor moraines at the southern margin (area G; Fig. 5) are situated on a topographic high to the north of a deep (>20 m) lake spillway that was excavated catastrophically in $~ 2003-2004$. This mound slopes northwestwards towards the glacier margin, forming a reverse slope, and it descends eastwards from a maximum height of $\sim 40 \mathrm{~m}$ down to a low-elevation outwash fan $(\sim 10 \mathrm{~m})$ at the southwestern edge of Fjallsárlón (Fig. 5). This topographic high point was interpreted as a large glacially overridden ice-contact fan/ramp by Evans et al. (2018b), based on the characteristics of the internal sediments exposed in the spillway walls. 
Minor moraines in assemblage $G$ have highly complicated planform geometries, with extremely sawtooth (or 'hairpin-shaped') moraines, localised superimposition, cross-cutting and bifurcations all being evident (Figs. 6 and 7). In several cases, the sawtooth moraines continue as, or are connected to, long ridge limbs (up to $\sim 35 \mathrm{~m}$ ) that are orientated obliquely to the moraine crestlines and sub-parallel to ice flow; this gives rise to moraine limbs that resemble the long arms of hairpins. Flutings also occasionally intervene moraine ridges and continue onto their ice-proximal slopes. Chains of minor moraines in this area are more fragmentary than elsewhere on the Fjallsjökull foreland, consisting of short sawtooth/hairpin fragments that are often $\sim 3-20 \mathrm{~m}$ in length (Fig 6). The highly complex nature of these minor moraines makes it challenging to connect them as coherent chains; however, more linear elements can be locally extrapolated to form chains that reach several hundreds of metres in length (up to $\sim 500 \mathrm{~m}$ ). Individual minor moraines in area $\mathrm{G}$ have heights of $\sim 0.2-1.5 \mathrm{~m}$ and widths of $\sim 2-7.5 \mathrm{~m}$. Within this moraine field, the moraines can be broadly divided into two groups, based on differences in their morphologies (Fig 8). The first group consists of relatively large, prominent moraines with heights of $\sim 0.7-1.5 \mathrm{~m}$ (mean $\sim 1.2 \mathrm{~m}$ ) and widths of $\sim 3-7.5 \mathrm{~m}$ (mean $\sim 5.1 \mathrm{~m}$ ), while the second group consists of comparatively smaller, lowerrelief moraines that attain heights of $\sim 0.15-0.7 \mathrm{~m}$ (mean $\sim 0.4 \mathrm{~m}$ ) and widths of $\sim 1-4 \mathrm{~m}$ (mean $\sim 2.4 \mathrm{~m}$ ). Moraines in the latter group are only easily identifiable and mappable on our high-resolution UAV-derived orthophotos and DEMs, whereas the larger moraines can be mapped from the coarser $(>0.5 \mathrm{~m}$ per pixel) remotely-sensed data. The two moraine populations are statistically distinguishable, exhibiting very highly statistically significant differences $(p<0.001)$ in both height and width. In cross-section, the moraines in area $\mathrm{G}$ are asymmetrical (steeper distal slopes) or have symmetrical, wedge-like, sharp-crested forms. Locally, the minor moraines have been subject to post-depositional breaching and are separated by small meltwater channels and outwash fans. Our repeat UAV-captured imagery 
also shows evidence of small, ephemeral streams draining meltwater ponded at the ice margin and winding through breaches in the moraine ridges. Additionally, localised, short-lived ponding occurs in the swales between the chains of minor moraines.

\subsection{Moraine sedimentology}

Moraine sections and test pits were created through 10 moraines to assess moraine-forming processes through detailed sedimentological analysis. Below, we present three example moraine exposures (Fig. 9), following the approach used in recent studies of minor/annual moraine formation elsewhere (e.g. Lukas, 2012; Reinardy et al., 2013; Chandler et al., 2016a). Based on the larger sample from across the moraine field, we regard the three examples as a representative subsample of the dominant facies associations found within moraines formed at the southern Fjallsjökull margin.

\subsubsection{Case Study 1: Moraine FJA-02}

This section (FJA-02; UTM coordinates: $430187 \mathrm{~m} \mathrm{E}, 7098835 \mathrm{~m} \mathrm{~N}$ ) was excavated through the northeastern limb of a sawtooth moraine, which is up to $\sim 0.8 \mathrm{~m}$ high, $47 \mathrm{~m}$ long, and up to $4 \mathrm{~m}$ wide. Moraine FJA-02 can be laterally connected (at its southwestern end) to other moraine fragments, forming a discontinuous sawtooth moraine that extends up to $\sim 160 \mathrm{~m}$ in length. In cross-section, this moraine exhibits a slightly asymmetric form, with a steeper distal $\left(\sim 30^{\circ}\right)$ than ice-proximal $\left(\sim 28^{\circ}\right)$ slope. The moraine surface is primarily covered by cobbles but with occasional boulders up to $\sim 0.5 \mathrm{~m}$ in a-axis length. Moraine FJA-02 formed sometime between 2003 and 2012; further age constraint is not possible due to a paucity of remotely-sensed data during this time period (see also Section 4.3). 
Description. An exposure created through the width of FJA-02 reveals that the moraine comprises two lithofacies (LFs 1 and 2; Fig. 9a). The section predominantly contains LF 1, which is a moderately consolidated, dark grey, silty-sandy, matrix-supported diamicton (Dmm). This Dmm is largely massive and structureless, although there are areas of weaklydeveloped fissility in the ice-proximal half of the section. Occasionally, there are small concentrations of pebbles within the Dmm, which form small gravel lenses/pods. Analysis of basalt clasts $(n=50)$ sampled from the massive diamicton $(\mathrm{Dmm})$ indicate that clasts in this lithofacies are dominantly subangular to subrounded $(\mathrm{RA}=0 \% ; \mathrm{RWR}=2 \% ; \mathrm{AvR}=2.32)$ and blocky in character $\left(\mathrm{C}_{40}=2 \%\right)$, with oblate and prolate clasts almost entirely absent (Fig. 9a). LF 2 comprises a massive to stratified, clast-supported diamicton ( $\mathrm{Dcm} / \mathrm{Dcs}$ ) that is relatively loose and easy to excavate. It occurs in the uppermost part of FJA-02 and is largely restricted to its distal side (Fig. 9a). In the top, central part of the exposure, the diamicton is structureless (Dcm) but laterally transitions to a stratified, clast-supported diamicton (Dcs) on the distal (left-hand) moraine slope, where it attains a maximum thickness of $0.25 \mathrm{~m}$. The internal stratification of the Dcs is conformable with the contact between the Dcs and underlying Dmm as well as the moraine surface slope; the Dcs layers dip $\sim 30^{\circ}$ to the southeast.

Interpretation. The moderately consolidated Dmm with areas of weak fissility (LF 1) has characteristics resembling those reported from subglacial traction tills in other active temperate glacier forelands in Iceland (cf. Evans 2000, 2017; Evans et al., 2006, 2016b, 2018a; Benediktsson et al., 2016; Jónsson et al., 2016). Moreover, the low angularity and blocky nature of the clasts found within LF 1 (Fig. 9a) are consistent with active transport at the ice-bed interface (cf. Boulton, 1978; Benn and Ballantyne, 1994; Lukas et al., 2013; 
Evans et al., 2018a). We therefore interpret LF 1 as a subglacial traction till, as in other icemarginal/annual moraines elsewhere in Iceland (e.g. Sharp, 1984; Bradwell, 2004a; Evans and Hiemstra, 2005; Evans et al., 2017, 2018a; Chandler et al., 2016a). The loose character of the upper diamictic facies (LF 2), its internal stratification and its conformity with the lower contact and moraine surface slope are consistent with a glaciogenic debris flow deposit (cf. Lawson, 1982; Lukas, 2007, 2012; Evans, 2018). This gravitational modification of the distal moraine slope was likely the result of debris and meltwater inputs directly from the glacier margin; mass flowage of the existing diamicton also likely occurred as meltwater was received directly from the adjacent, melting glacier (cf. Sharp, 1984; Evans and Hiemstra, 2005). The internal composition and sedimentary architecture of moraine FJA-02 are comparable to those of 'Type A' moraines reported by Sharp (1984), which were argued to have formed through (a) extrusion of water-soaked subglacial traction till, (b) pushing of the extruded subglacial till, and (c) sediment flow activity on the moraine distal slopes. Thus, we interpret moraine FJA-02 as a push/squeeze moraine that has experienced minor postdepositional modification of its distal slope by mass flow. Formation of this moraine through a combination of submarginal squeezing and ice-marginal pushing is also supported by its sawtooth planform geometry: the extrusion of water-soaked subglacial tills through marginal crevasses and into crenulations or pecten of the glacier margin, and subsequent pushing, would lead to a planform that mimics the morphology of the glacier snout (cf. Price, 1970; Sharp, 1984; Evans and Hiemstra, 2005; Chandler et al., 2016a; Evans et al., 2016a).

\subsubsection{Case Study 2: Moraine FJA-05}

Moraine FJA-05 (UTM coordinates: $430643 \mathrm{~m} \mathrm{E}, 7099092 \mathrm{~m} \mathrm{~N}$ ) is a $\sim 12 \mathrm{~m}$ long, $\sim 3-3.5 \mathrm{~m}$ wide and $\sim 0.7-0.8 \mathrm{~m}$ high fragment that has a tight hairpin-shaped planform; the moraine can 
be extrapolated laterally to form a discontinuous sawtooth moraine that reaches up to $\sim 65 \mathrm{~m}$ in length. In cross-section, the moraine is asymmetrical along most of its length, with a steeper distal $\left(32-36^{\circ}\right)$ than proximal $\left(28-30^{\circ}\right)$ slope. Moraine FJA-05 is situated at the foot of a reverse slope down towards the present-day ice margin, in close proximity to a small area of ponding in front of an ice-cored esker (Fig. 6). Based on our UAV-captured imagery, this moraine was formed between September 2017 and August 2018. An exposure was created at the northeastern end of moraine FJA-05 and perpendicular to the crestline (azimuth: 036-216º.

Description. The sediments exposed in FJA-05 (Fig. 9b) comprise a variety of lithofacies: (i) massive, matrix-supported, silty-sandy, moderately compacted diamicts (Dmm) that contain areas of weakly-developed fissility and clasts with maximum $a$-axes lengths of $0.2 \mathrm{~m}$; (ii) layers and lenses of massive (GRm) and horizontally-bedded (GRh) granule gravels that are 3-26 cm thick; (iii) thin, centimetre-scale layers/lenses of moderately sorted medium and coarse sand (Sm and $\mathrm{Sh}$ ) that attain maximum thicknesses of $6 \mathrm{~cm}$; and (iv) deformed lenses/pods of massive or laminated silts $(\mathrm{Fm}, \mathrm{Fl})$ that reach thicknesses of $17 \mathrm{~cm}$. The laminated silts $(\mathrm{Fl})$ also contain occasional thin, millimetre-scale (up to $\sim 5 \mathrm{~mm}$ ) stringers of outsized coarse sand and granule gravel particles. The bulk of FJA-05 consists of the massive, matrix-supported diamicton (Dmm), which contains clasts that exhibit low levels of angularity $(\mathrm{RA}=6 \%)$ and have blocky forms $\left(\mathrm{C}_{40}=4 \%\right)$ (Fig. 9b). Sorted sediment lenses ( $\mathrm{Sm}, \mathrm{Fm}$, and $\mathrm{Fl}$ ) within this section predominantly occur towards the base, alongside layers/lenses of granule gravels (GRm, GRh). The right-hand silt unit (Fm) is interfingered with granule gravel and contains a few sporadic pebbles. Locally, the sorted silt units wrap around the undersides of clasts. Higher up in the exposure (at $0.6-1.1 \mathrm{~m}$ ), a $\sim 5 \mathrm{~cm}$ thick, discontinuous layer of horizontally-bedded coarse sand (Sh) has been folded into a large- 
scale, close, anticlinal fold with an amplitude of $\sim 0.3 \mathrm{~m}$ and a wavelength of $\sim 0.9 \mathrm{~m}$ (Fig.

9b). Bedding within the folded sand layer is undisturbed. Measurements of the strike and dip of the contacts between the Sh and Dmm units allows the calculation of the fold axis, which dips at $36^{\circ}$ towards the $\mathrm{NE}\left(032^{\circ}\right)$. The left-hand (distal) side of the moraine is partially draped by a unit of horizontally-bedded granule gravel that reaches up to $13 \mathrm{~cm}$ in thickness; the Dmm unit in the right-hand (ice-proximal) side of the moraine FJA-05 is overlain by a layer of massive granule gravel that attains a maximum thickness of $26 \mathrm{~cm}$.

Interpretation. In agreement with the interpretation of the massive, matrix-supported diamicton (Dmm; LF 1) in moraine FJA-02 (above), the diamicts in FJA-05 are argued to have originally been deposited as subglacial traction tills. As in moraine FJA-02, and other Icelandic ice-marginal moraines, the subglacial traction till was most likely advected to the glacier margin and extruded through marginal crevasses before being incorporated into the moraine (cf. Price, 1970; Sharp, 1984; Evans and Hiemstra, 2005). The sorted sand lenses/layers (Sm, Sh) and granule gravels that occur within LF 1 in this exposure are suggested to have originally been deposited by meltwater either flowing along the glacier margin or in a submarginal position, with the grain-size variations and sorting reflecting changes in flow velocity (Maizels, 1993; Marren, 2002, 2005; Collinson et al., 2006). Switches from flowing meltwater to stagnant meltwater and ice-marginal ponding may be responsible for the deposition of the silt units (Fm, Fl). This is entirely consistent with evidence for (short-lived) ponds at the glacier margin on our UAV-captured imagery.

The reconstructed orientation $\left(032^{\circ}\right)$ of the fold axis in FJA-05 is very similar to that of the moraine crestline (azimuth: 036-216 ), and both are orthogonal to the local ice-flow direction (NW-SE). Since moraine crestlines and folds are both formed at right angles to applied 
stress, the geometric correspondence between the moraine crestline, fold axis and ice-front indicates that this moraine was subject to lateral compressive stress (i.e. pushing). Thus, FJA05 is interpreted as a push moraine. A push mechanism for construction of this minor moraine is wholly compatible with the lithofacies units exposed in moraine FJA-05: icemarginal pushing would have facilitated the incorporation of both subglacial traction till (Dmm) and pre-existing, proglacial glaciofluvial sediments (Sm, Sh, Fm, Fl, GRm, GRh) in the moraine. The inclusion of glaciofluvial sediments within minor moraines has been linked to submarginal/subglacial freeze-on in Iceland and elsewhere (cf. Andersen and Sollid, 1971; Harris and Bothamley, 1984; Krüger, 1993, 1995, 1996; Matthews et al., 1995; Reinardy et al., 2013), but the large-scale fold and preservation of internal bedding within the folded sands in FJA-05 suggests that the sediments were unfrozen and subject to ductile failure (folding) during moraine formation (cf. Lukas, 2012). Indeed, the internal architecture of this moraine is inconsistent with the emplacement of glaciofluvial sediments by freeze-on as such facies associations normally take the form of upglacier-dipping slabs within moraines (cf. Krüger, 1993, 1995, 1996; Reinardy et al., 2013). Had the sediment been frozen, brittle deformation and reverse faulting of the proglacial glaciofluvial sediments would also be expected (cf. Sharp, 1984; Krüger, 1994, 1995), but such deformation structures are absent in the exposure. The sedimentary architecture of FJA-05 therefore suggests that this moraine was constructed by uninhibited pushing and folding of extruded subglacial traction tills and pre-existing glaciofluvial sediments into a push moraine. The extremely sawtooth (hairpinshaped) planform of the moraine resulted from the operation of these processes at a heavilyindented sector of the glacier margin (cf. Chandler et al., 2016a; Evans et al., 2016a).

Lastly, the granule gravels (GRm, GRh) present on the moraine slopes are suggested to reflect post-depositional gravitational modification of the moraine, possibly via the transfer of 
ice-slope colluvium onto the moraine crestline/surface and subsequent mass movement (cf. Sharp, 1984). Collectively, FJA-05 is thus interpreted as an ice-marginal push moraine that has been gravitationally modified.

\subsubsection{Case Study 3: Moraine FJA-06}

Moraine FJA-06 (UTM coordinates: $430685 \mathrm{~m} \mathrm{E,} 7099075 \mathrm{~m} \mathrm{~N}$ ) is a sharp-crested moraine that is $\sim 55 \mathrm{~m}$ long, $\sim 3$ wide and up to $\sim 0.7 \mathrm{~m}$ high. This moraine lies on a reverse slope that dips both northwestwards and northeastwards towards the present-day glacier margin. The moraine has a broadly linear but gently crenulated planform geometry, and it trends down the reverse slope from southwest to northeast. At its northeastern end, the moraine ridge bifurcates, with a moraine fragment forking off in an easterly direction. From the bifurcation, moraine FJA-06 can be laterally connected to a chain of moraine ridges that extend east/northeastwards for a further $\sim 65 \mathrm{~m}$. FJA-06 has a symmetrical, steep-sided cross-profile, with both the ice-proximal and distal slopes dipping at $36^{\circ}$. Based on available remotelysensed data, this moraine ridge was formed during 2014/2015.

Description. This exposure was excavated approximately orthogonal $\left(176^{\circ}\right)$ to the moraine crestline in a re-entrant, where the moraine arcs inwards from northeast to west and then turns south-southwestwards (Fig. 9c). Of the moraine sections presented here and examined during fieldwork, moraine FJA-06 is the least complex, consisting entirely of a single lithofacies, which is a moderately compacted, dark grey/brown, silty, matrix-supported, massive diamicton (Dmm) (Fig. 9c). Although the diamicton is largely massive and structureless, there are some areas of poorly-developed fissility in the ice-proximal (left-hand) side of moraine FJA-06. Alongside this, there is an increase in consolidation from right to left in the 
exposure, with sediment in the right-hand (distal) part of the exposure being looser and easier

to excavate. Cobble-sized clasts are relatively sparse in the Dmm and, as in moraines FJA-02 and -05 , the clasts are predominantly subangular to subrounded $(\mathrm{RA}=8 \% ; \mathrm{RWR}=6 \%$; $\mathrm{AvR}$ $=2.26)$ and blocky $\left(\mathrm{C}_{40}=2 \%\right)$, with oblate and prolate clasts almost entirely absent (Fig. 9c).

Interpretation. As argued for moraines FJA-02 and FJA-05, the characteristics of the diamicton in moraine FJA-06 (e.g. moderate consolidation, weakly-developed fissility) are consistent with those of subglacial traction tills found elsewhere in Iceland, including within ice-marginal moraines. The morphological characteristics of clasts within the diamicton (i.e. high levels of blockiness, low angularity) are also entirely consistent with transport in the subglacial traction zone (cf. Benn and Ballantyne, 1994; Lukas et al., 2013; Evans et al., 2018). On this basis, we interpret the Dmm in moraine FJA-06 as a subglacial traction till. The emplacement of subglacial traction till in Icelandic ice-marginal/annual moraines has been associated with various ice-marginal/submarginal processes, namely squeezing (e.g. Price, 1970), pushing (e.g. Sharp, 1984) and submarginal/subglacial freeze-on (e.g. Krüger, 1995; Evans and Hiemstra, 2005). Push moraines usually exhibit clear steeper distal slopes and asymmetric cross-profiles (cf. Worsley, 1974; Birnie, 1977; Matthews et al., 1979; Sharp, 1984; Chandler et al., 2016a), while moraines formed by submarginal freeze-on have internal sedimentary architectures characterised by distinct sediment slabs (cf. Krüger, 1993, 1995, 1996; Matthews et al., 1995; Evans and Hiemstra, 2005; Reinardy et al., 2013; Hiemstra et al., 2015; Chandler et al., 2016a). These characteristics are not apparent in moraine FJA-06. As this moraine is composed entirely of subglacial traction till and exhibits a symmetrical, wedge-like form, we suggest moraine FJA-06 is the geomorphological expression of submarginal till wedge thickening mainly via the advection and extrusion of subglacial till from beneath the glacier margin (i.e. by submarginal squeezing; cf. Price, 1970; Evans and 
Hiemstra, 2005). The squeeze moraine may have subsequently undergone ice-marginal pushing (cf. Sharp, 1984; Chandler et al., 2016a), although the absence of a distinct asymmetric cross-profile and widespread deformation structures in the moraine implies that any ice-marginal pushing was relatively ineffective.

\subsubsection{Debris transport pathways}

Covariance analysis of basalt clast samples from the three moraine sections described above and two additional moraines was undertaken to assess debris transport pathways, following well-established procedures (e.g. Benn and Ballantyne, 1993, 1994; Evans, 2010; Brook and Lukas, 2012; Lukas et al., 2013). The moraine samples were compared with control samples from Fláajökull, an active temperate outlet glacier of the southern margin of Vatnajökull (see

Evans et al., 2016a). Fláajökull exhibits dominant subglacial and fluvial erosion and transport, with multiple and complex transfers of material between the subglacial and glaciofluvial realms; thus, the subglacial tills have inherited glaciofluvial roundness characteristics (Lukas et al., 2013; Evans et al., 2018). This inter-mixing of glaciofluvial and subglacial material appears to be characteristic of active temperate outlet glaciers in southeast Iceland (e.g. Evans, 2000), and the Fláajökull control samples are therefore considered suitable reference values. We also compared the moraine samples against aggregate envelopes for push moraine, glaciotectonite and undefined/overprinted till samples from elsewhere in Iceland (see Evans et al., 2018a).

All the moraine samples from Fjallsjökull show very low levels of angularity $(\mathrm{RA}=0-8 \%)$ and high levels of blockiness $\left(\mathrm{C}_{40}=2-8 \%\right)$, with prolate and oblate clasts almost entirely absent; roundness values are similarly low $(\mathrm{RWR}=0-10 \% ;$ AvR $=2.26-2.60)$. Visually, 
there was also an abundance of striated and facetted blocky clasts within all the moraines. As argued in preceding sections, these shape characteristics are consistent with active transport of the clasts in the subglacial traction zone (e.g. Boulton, 1978; Benn and Ballantyne, 1994; Lukas et al., 2013; Evans et al., 2016b, 2018a). This initial interpretation of clast shape data is substantiated by comparison of the moraine samples with the control envelopes on covariance plots of both RA-C $\mathrm{C}_{40}$ and $\mathrm{RWR}-\mathrm{C}_{40}$ : the moraine samples plot closest to the subglacial/till control envelopes, and they are clearly distinguishable from the fluvial and supra/extraglacial control samples (Fig. 10). Indeed, the moraine samples appear to record a strong signature of subglacial wear, corresponding most closely with the clast forms displayed within overprinted tills (cf. Evans et al., 2018a). The clast shape data therefore indicate the dominance of subglacially-transported material within the minor moraines, which agrees with the sedimentological evidence for moraine formation primarily by squeezing and/or pushing of subglacial traction tills.

\subsection{Moraine chronology and formation frequency}

The approximate age of the minor moraines at the southern Fjallsjökull margin, as well as moraine formation frequency, are assessed here using available remotely-sensed data. The assemblage of minor moraines is bounded to the south/southeast by a lake spillway and an outwash fan (see Figs. 5 and 6), both of which were formed around 2003 based on aerial photographs captured by Loftmyndir ehf (photo 0336-20-0432; https://www.map.is/loftmyndir/). The southern glacier margin was situated against the northern edges of the lake spillway and outwash fan at that time, which provides a bracketing age for the minor moraines (i.e. the moraines must have formed at some stage between 2003 and 2019). 
The glacier margin experienced overall retreat up until 2012 (Fig. 11), when the LiDAR data for the Fjallsjökull foreland were collected (see Section 3.1). Retreat along the southern margin was variable during this 9-year interval, ranging from $\sim 85$ to $300 \mathrm{~m}\left(\sim 9-33 \mathrm{~m} \mathrm{a}^{-1}\right)$. Minor moraines were formed unevenly along the southern margin in 2003-2012, reflecting the differential retreat of the ice margin (Fig. 11a). A limited number of moraine $(n=5)$ were formed in the easternmost parts of the assemblage. Further westwards, eight prominent $(\sim 1-$ $1.5 \mathrm{~m}$ high), densely-spaced ( 5-20 m) moraine ridges occur between the 2003 and 2012 glacier limits; narrow, low-amplitude ( 0.2-0.4 m high) moraines are found in between these pronounced ridges, but the low-amplitude moraines are only identifiable and mappable on our high-resolution UAV-captured imagery (see Fig. 6).

In the western-central parts of the assemblage, where ice-marginal retreat was greatest, more than nine distinct minor moraines were formed during the nine-year period (Fig. 11). The high number of complex, sawtooth or hairpin-shaped moraines are most clearly visible on UAV-captured imagery for this area (Figs. 7 and 11c), with many of these narrow, lowamplitude minor moraines being below the resolution of the LiDAR data (Fig. 11a). These minor moraines appear to occur in sets/systems, with smaller, lower-amplitude $(\sim 0.2-0.5 \mathrm{~m}$ high) ridges occurring between larger, more pronounced $(\sim 0.7-1.2 \mathrm{~m}$ high) moraines (see also Section 4.1). Nonetheless, the number of prominent moraine ridges $(n>13)$ is greater than the time elapsed (9 years), and there are additional overridden and dismembered minor moraines to the southeast (Fig. 11). Thus, moraine counting between the two bracketing icemarginal positions indicates areas of sub-annual moraine formation between 2003 and 2012 .

Ice-marginal fluctuations were spatially variable along the margin in the period 2012-2014 (Fig. 11b). The eastern sections of the ice margin were relatively stable during this time 
interval, but with some localised, small re-advances $(\sim 5-15 \mathrm{~m})$. To the west, there are sectors of extensive, rapid retreat (up to $\sim 175 \mathrm{~m}$ ), associated with glacier collapse over former submarginal and englacial channels (Fig. 11b). Comparison of the 2012 and 2014 imagery reveals that annual moraine formation took place along these western sections. In contrast, a single, more prominent ( $1.5 \mathrm{~m}$ high) moraine ridge was deposited along much of the eastern parts of the margin, which can be linked to a minor net re-advance in the 2012-2014 interval.

The vast majority of the southern glacier margin experienced overall retreat between 2014 and 2016, but minor/ice-marginal moraine formation only occurred along a 500 m section in the eastern part of the UAV survey area. There was a distinct change to the landsystem signature to the west, characterised by ice-cored/hummocky terrain and the emergence of a former englacial conduit fill (esker) on the ice surface (Fig. 6; cf. Evans et al., 2018b). Comparison of the 2014 satellite imagery and our 2016 UAV imagery reveals that sub-annual moraine formation occurred in the eastern part of the survey area, with 3 or 4 moraine ridges deposited along most of this sector (Fig. 11d). In some restricted areas, as many as seven small ( 0.2-0.6 m high) moraines were formed during 2014-2016. Seasonal re-advances of the glacier margin have also resulted in localised superimposition of moraines (Fig. 11d).

Our UAV surveys along the southern Fjallsjökull margin in 2016-2019 record overall recession $\left(\sim 5-43 \mathrm{~m} \mathrm{a}^{-1}\right)$, but with a localised re-advance of up to $\sim 20 \mathrm{~m}$ in the eastern part (Fig. 12). Significantly, our UAV imagery captures moraines being formed sub-annually (3-6 moraines per year) throughout this period, including along the sector displaying overall readvance (Fig. 13). Minor moraines were formed most frequently during the first year (September 2016- September 2017), when 3-5 moraine ridges were constructed along debris free parts of the ice margin ( $430 \mathrm{~m}$ long sector). Minor moraine formation became more 
restricted and fragmentary in subsequent years owing to re-advance along the eastern part of the margin (see Fig. 12) and southwards migration of an ice-cored esker on the glacier surface (see Fig. 6). Where overall re-advances $\left(4-12 \mathrm{~m} \mathrm{a}^{-1}\right)$ of the glacier margin took place, minor (sub-annual) moraines formed during the previous seasonal cycle were largely overridden and obliterated, but with localised moraine superimposition also occurring (Fig. 13). Despite these small net ice-marginal re-advances, multiple minor moraines ( $\geq 3$ ridges) were still formed at some sections of the glacier margin in each year. In the case of the last interval (2018-2019), sub-annual moraine formation occurred in a nine-month period (August 2018-May 2019) and it is possible that further minor moraines were formed during the remainder of the 2019 melt season. Our repeat UAV surveys thus provide clear, unequivocal evidence for sub-annual moraine formation at Fjallsjökull in three successive years. To our knowledge, this is the first time that sub-annual moraine formation has been captured and demonstrated by repeat aerial imagery, with sub-annual moraines previously assumed by counting moraines between bracketing ice-marginal positions (cf. Krüger, 1995; Chandler et al., 2016a).

In summary, available remotely-sensed data imply that minor moraines were formed subannually at Fjallsjökull between 2003 and 2012, based on moraine counting. A short phase of localised annual moraine formation followed in 2012-2014, before a return to sub-annual moraine formation between 2014 and 2019. Our time series of repeat UAV imagery (20162019) provides particularly compelling evidence for high-frequency moraine formation at Fjallsjökull.

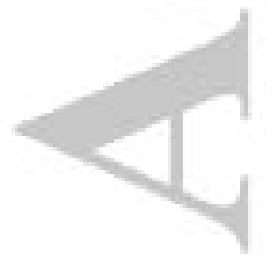




\section{5 | SYNTHESIS AND DISCUSSION}

\subsection{Moraine-forming processes}

Geomorphologically, the minor moraines at the southern Fjallsjökull margin are characterised by their distinctive sawtooth or hairpin-shaped planforms; these individual sawtooth or hairpin fragments are arranged as densely-spaced, discontinuous chains that extend for up to several hundreds of metres. Our sedimentological investigations of these minor moraines suggest they were formed by squeezing and/or pushing of subglacial traction tills. Clastshape data from the minor moraines are also a strong indicator of the dominance of subglacial processes and transport pathways at Fjallsjökull, with all clast samples exhibiting a clear subglacial signature (Section 4.2.4; cf. Boulton, 1978; Benn and Ballantyne, 1993, 1994; Lukas, 2007; Lukas et al., 2013; Evans et al., 2018a).

The construction of the push/squeeze moraines at Fjallsjökull can be linked to the subglacial deforming layer model and the advection of subglacial tills to the glacier margin (cf. Price, 1970; Sharp, 1984; Evans and Hiemstra, 2005; Chandler et al., 2016a; Evans et al., 2018). Subglacial processes, such as lodgement, deformation and ploughing, advect deforming layer sediments through the ablation zone towards the glacier snout, leading to increased sediment availability at the margin and the concomitant production of down-ice thickening till wedges (cf. Evans and Hiemstra, 2005; Evans et al., 2018). At the glacier margin, advected subglacial tills are extruded (or 'squeezed') through marginal radial crevasses and into crenulations or pecten of the margin (cf. Price, 1970). This process of ice-marginal squeezing, together with bulldozing/pushing, leads to the construction of ice-marginal moraines with geometries that mirror the morphology of the ice margin at that time (cf. Price, 1970; Sharp, 1984; Evans and 
Twigg, 2002; Evans and Hiemstra, 2005; Chandler et al., 2016a; Evans et al., 2016a). In essence, the Fjallsjökull minor moraines can be regarded as 'till wedges', with thickening of the subglacial deforming layer and submarginal till wedge production expressed in the landform record as the moraines (cf. Price, 1970; Evans and Hiemstra, 2005; Evans, 2018).

In addition to this connection between the moraines and the subglacial deforming layer, the architecture and orientation of marginal crevasses are also important controls on the moraine forms and patterns: squeezing of the advected tills at a heavily-crevassed glacier margin is responsible for the extremely sawtooth forms of the moraines (cf. Price, 1970; Chandler et al., 2016a; Evans et al., 2016a, 2017). Where deformable subglacial tills are squeezed into longitudinal crevasses, elongated moraine ridge limbs develop, giving rise to the striking, exaggerated sawtooth (or hairpin) moraines at Fjallsjökull (Figs. 6 and 7). We suggest that the long ridge limbs are also at least partially submarginal features and thus represent crevasse infills (crevasse-squeeze ridges) (cf. Evans et al., 2016a). On this basis, we propose that the hairpin moraines at Fjallsjökull are best regarded as hybrid forms, comprising push/squeeze moraines (the outer till wedge) that continue as crevasse-squeeze ridges (the long ridge limbs) (cf. Evans et al., 2016a, 2017; Evans and Ewertowski, 2018). Changes to the architecture of the longitudinal crevasses over successive seasonal cycles, together with fluctuations of the actively-retreating glacier margin, result in the development of the highly complex and locally superimposed moraine and crevasse-squeeze ridge patterns (Figs. 6 and 7).

Deformable sediments are also manifest in the form of flutings that are closely associated with the minor moraines at Fjallsjökull (Fig. 7), which similarly indicates a genetic link between these landforms. The spatial relationships between the moraines and flutings, with 
flutings lying beneath the moraines, can be explained by linkages with the subglacial deforming layer. Specifically, the processes of subglacial deformation or ploughing that are responsible for the production of the flutings also result in the advection of till to the glacier snout, where squeezing of the deformable tills into crevasses leads to the formation of moraines as well as crevasse-squeeze ridges (cf. Price, 1970; Boulton, 1976; Sharp, 1984; Boulton and Hindmarsh, 1987; Benn, 1994; Boulton and Dobbie, 1998; Boulton et al., 2001; Evans and Twigg, 2002; Evans et al., 2018a).

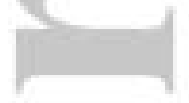

The process-form regime responsible for the formation of the push/squeeze moraines at Fjallsjökull, along with the associated crevasse-squeeze ridges, is comparable to that observed at other Icelandic active temperate outlet glaciers (e.g. Sharp, 1984; Evans and Hiemstra, 2005; Chandler et al., 2016a; Evans et al., 2016a, 2017; Evans and Ewertowski, 2018; Evans et al., 2018c). Our sedimentological data are also in general agreement with seminal work by Price (1970), who proposed that squeezing of water-soaked tills from beneath the glacier margin was responsible for moraine formation at Fjallsjökull. However, our investigations indicate that squeezing was also coupled with pushing during the past $\sim 15$ years, as shown elsewhere in Iceland (e.g. Sharp, 1984; Evans and Hiemstra, 2005; Chandler et al., 2016a). The presence of a clear, large-scale fold in moraine FJA-05, and thus definitive evidence for ice-marginal pushing, is a rare case in the context of Icelandic minor/annual moraines. Typically, such moraines consist (almost) entirely of subglacial traction till, occasionally draped with thin debris/mass flow layers on the moraine slopes (e.g. moraines FJA-02 and -06; cf. Price, 1970; Sharp, 1984; Boulton, 1986; Chandler et al., 2016a). The coarse texture of the sediments and absence of textural contrasts within most Icelandic minor moraines are not conducive to displaying ductile deformation structures and large-scale folding particularly well, hence the infrequent occurrence of large-scale folds. Other studies 
have also emphasised the role of submarginal freeze-on of till slabs in submarginal till wedge thickening and moraine formation at Icelandic glaciers (cf. Krüger, 1993, 1994, 1995, 1996; Evans and Hiemstra, 2005), but we found no evidence for this process; the sedimentological data indicate that submarginal till deformation and extrusion was ubiquitous.

Compared to previous models of minor (annual) moraine formation elsewhere (i.e. outside of Iceland), the pervasiveness of subglacial traction till within the moraines at Fjallsjökull and the role of ice-marginal squeezing in till emplacement represent the crucial differences. In many cases, minor/annual moraines elsewhere comprise pre-existing, secondary glaciogenic sediments (e.g. glaciofluvial sediments) that have been pushed/bulldozed into a ridge, or till was emplaced in the moraine by subglacial freeze-on (cf. Andersen and Sollid, 1971; Harris and Bothamley, 1984; Matthews et al., 1995; Winkler and Matthews, 2010; Lukas, 2012;

Reinardy et al., 2013; Hiemstra et al., 2015; Wyshnytzky, 2017). Other differences from hitherto-proposed models of minor (annual) moraine genesis include the absence of evidence for (i) snow-cover having a key role in moraine formation or post-depositional modification (cf. Birnie, 1977; Sharp, 1984), (ii) dead-ice incorporation within push moraines (cf. Sharp, 1984; Lukas, 2012; Wyshnytzky, 2017), or (iii) deposition of terrestrial ice-contact fans (Lukas, 2012). Again, this highlights the dominance of submarginal till deformation, squeezing and pushing at Fjallsjökull.

As noted above, the combination of ice-marginal squeezing and pushing, together with submarginal freeze-on in some situations, have been widely recognised as contributing to minor/annual moraine formation at Icelandic outlet glaciers (cf. Sharp, 1984; Boulton, 1986; Evans and Hiemstra, 2005; Chandler et al., 2016a; Evans et al., 2016a, 2017). However, the operation of these submarginal and ice-marginal processes over a single seasonal cycle is 
usually linked to the construction of a single submarginal till wedge and push/squeeze moraine per year (cf. Evans and Hiemstra, 2005). In contrast, we have established that minor moraines have been formed sub-annually at Fjallsjökull for much of the past $\sim 15$ years, implying that subglacial deforming tills are efficiently and frequently advected to the glacier margin. Rather than manifesting as a single composite submarginal till wedge or annual moraine, we suggest that multiple till emplacement events over a single seasonal cycle produce multiple, discrete till wedges (moraines) at Fjallsjökull (cf. Evans and Hiemstra, 2005; Evans et al., 2016b).

Our morphometric analyses of the sub-annual moraines have revealed that they consist of two statistically distinct populations (Fig. 8; Section 4.1), namely a group of particularly prominent moraine ridges (mean height $\sim 1.2 \mathrm{~m}$ ) and a group of less pronounced (mean height $\sim 0.4 \mathrm{~m}$ ) moraines. Frequently, these moraines occur as sets/systems that comprise (i) a particularly prominent outer moraine ridge and (ii) several less pronounced inner ridges per year. Based on our sedimentological investigations, we hypothesise that these sets/systems constitute (i) a push moraine constructed by pushing of extruded subglacial tills during a winter re-advance (cf. Sharp, 1984; Chandler et al., 2016a), and (ii) a succession of squeeze moraines formed during the melt season (cf. Price, 1970). General support for the production of moraines purely by ice-marginal squeezing (ii) is also provided by two earlier studies at Fjallsjökull, which both recognised that ice-marginal squeezing can construct moraines independently of the push mechanism at this outlet (Price, 1970; Roberts, 1995).

In accordance with the subglacial deforming layer model and marginal-thickening till wedge architecture discussed above, deformable sediments are supplied to the glacier margin for squeezing by the advection of tills through the ablation zone (cf. Boulton, 1996; Evans et al., 
2016b, 2018a). However, the process of ice-marginal squeezing itself is primarily driven by glaciostatic loading of saturated tills, with ice overburden pressures resulting in squeezing of the water-soaked, semi-liquid subglacial tills into marginal radial crevasses (cf. Price, 1970; Evans and Hiemstra, 2005). Ice-marginal squeezing is facilitated by (a) increased meltwater penetrating to the bed during the melt season and saturating subglacial sediments, (b) poor drainage conditions associated with the increased meltwater, (c) poor drainage conditions associated with a reverse slope/ depositional overdeepening, and (d) relatively low basal shear stresses in the submarginal zone that gradually decrease towards the glacier margin (cf. Price, 1970; Chandler et al., 2016a; Evans et al., 2016a, 2018a; Evans and Ewertowski, 2018). According to this model, the squeeze moraines effectively record melt events during summer retreat, rather than ice-marginal oscillations.

\subsection{Conceptual model of sub-annual moraine formation}

Based on the integration of our geomorphological, sedimentological and remotely-sensed data, we suggest that sub-annual moraines formed at Fjallsjökull by the following sequence of events (Fig. 14). During the melt season, an influx of meltwater to the glacier bed saturates the underlying subglacial sediments and elevates porewater pressures. This saturation of the subglacial sediments and increase in porewater pressures, together with gradual reduction in basal shear stresses towards the glacier margin, leads to submarginal deformation and icemarginal squeezing (cf. Andrews and Smithson, 1966; Price, 1970; Sharp, 1984; Evans and Twigg, 2002; Evans and Hiemstra, 2005; Evans, 2018). By late summer, water-soaked tills have been extruded through marginal crevasses to form squeeze moraines, as well as crevasse-squeeze ridges (Fig. 14a). During the subsequent winter re-advance (Fig. 14b), the extruded subglacial sediments/squeeze moraines are subject to pushing by the advancing 
glacier margin, leading to lateral compression as well as ductile deformation and folding in some cases (e.g. FJA-05: Fig. 9b). This results in the construction of a single, relatively prominent $(\sim 0.7-1.5 \mathrm{~m}$ high) push moraine. Localised re-working of the distal moraine slope may subsequently take place due to gravitational and glaciofluvial activity, as in moraines FJA-03 and FJA-05. It is also possible that submarginal freeze-on of subglacial tills may (locally) occur during the winter, owing to the penetration of the winter freezing front (cf. Krüger, 1993, 1995, 1996; Evans and Hiemstra, 2005). Subsequent thawing of this till layer during the early melt period would make the formerly frozen tills increasingly susceptible to submarginal deformation, and they could potentially then be squeezed and moulded into a secondary moraine ridge located inside the winter push moraine (cf. Evans and Hiemstra, 2005). Upon commencement of the melt season, meltwater fluxes to the glacier bed increase due to enhanced surface melting. In turn, the influx of meltwater to the base of the glacier will induce ice-marginal squeezing in late spring/early summer (Fig. 14c). Our UAV survey in May 2019 revealed that small ( 0.2-0.4 m) sawtooth ridges had already been constructed inside the 2018-2019 winter push moraine, thus implying ice-marginal squeezing and squeeze-moraine formation occurs in the early part of the melt season. As the melt season proceeds, continued ice-marginal squeezing and ice-marginal retreat leads to construction of multiple inset squeeze moraines (Fig. 14d). Re-advance of the glacier margin during the subsequent winter will lead to pushing and ice-marginal deformation of subglacial sediments extruded over the melt season. Provided that this winter re-advance does not exceed glacier retreat during the previous summer, sub-annual moraines will be preserved (Fig. 14e).

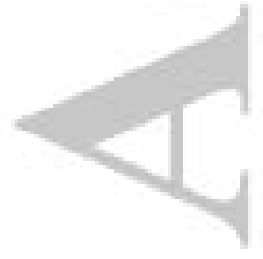




\subsection{Controls on sub-annual moraine formation}

The formation of minor/annual moraines at Icelandic active temperate glacier margins has previously been shown to reflect seasonally-driven submarginal and ice-marginal processes active in a given year (e.g. Sharp, 1984; Boulton, 1986; Krüger, 1995; Chandler et al., 2016a). In particular, phases of (sub-)annual moraine formation have been associated with periods of above-average summer temperatures in Iceland, where the spacing between individual moraines is primarily controlled by variations in the summer temperature signal from year to year (Boulton, 1986; Krüger, 1995; Bradwell, 2004a; Bradwell et al., 2013; Chandler et al., 2016a, b). This temporal coincidence between annual moraine spacing and years of elevated summer temperatures indicates Icelandic glacier margins have very short reaction times and react to temperature variations on a sub-annual/seasonal timescale (cf. Bradwell et al., 2013).

At Fjallsjökull, sub-annual moraine formation (2003-2019) coincides with a 25-year period of above-average summer air temperatures, which began in 1994 (Fig. 15). Between 2003 and 2018, the mean positive deviation from the 1961-1990 summer air temperature average at Fagurhólsmyrí $\left(9.17^{\circ} \mathrm{C}\right)$ was $0.91^{\circ} \mathrm{C}$. There are also seven years in the $2003-2018$ period that experienced positive anomalies $>1{ }^{\circ} \mathrm{C}$; the maximum deviation from the $1961-1990$ average was $1.70^{\circ} \mathrm{C}$ (in 2014). This warm phase, and the period of sub-annual moraine formation, coincides with a period of sustained, rapid ice-front retreat at Fjallsjökull: point measurements by Jöklarannsóknafélag Íslands (the Icelandic Glaciological Society) indicate the ice-front retreated on average $\sim 47 \mathrm{~m} \mathrm{a}^{-1}$ between 2003 and 2014 (Fig. 15). Similarly, an older sequence of possible annual moraines ( 1937-1962; based on aerial photography) corresponds with a period of above-average temperature as well as a long-term trend of ice- 
marginal retreat (Fig. 15). These observations imply that (sub-)annual moraine formation at Fjallsjökull may, at least partly, be linked to periods of enhanced glacier retreat and elevated summer temperatures; this is in general agreement with findings from other Icelandic outlet glaciers (cf. Bradwell et al., 2013; Chandler et al., 2016a, b).

Above-average summer temperatures and concomitant enhanced glacier recession could (indirectly) control the frequency of moraine formation at Fjallsjökull in two important, interlinked ways. A key factor influencing our proposed process-form regime is meltwater flux to the glacier bed, with the influx of meltwater during the melt season leading to icemarginal squeezing (Fig. 14; cf. Price, 1970). Enhanced glacier surface melting, and an increased frequency of large-magnitude melt events, are a likely consequence of phases of above-average temperatures (as recorded in the past 25 years); in turn, this will lead to greater quantities of meltwater descending to the base of the glacier. An increased influx of meltwater to the glacier bed could promote submarginal deformation and ice-marginal squeezing by saturating the subglacial sediments and elevating porewater pressures, with meltwater pulses during major melt events leading to squeeze-moraine formation (cf. Price, 1970; Evans and Hiemstra, 2005; Chandler et al., 2016a). Above-average temperatures will also lead to enhanced glacier retreat during the melt season, as implied by the measurement data (Fig. 15). We suggest that this combination of (a) enhanced meltwater influx to the bed and (b) strong summer glacier recession would allow multiple squeeze moraines to be formed during summer retreat. Importantly, it is strong summer glacier retreat, rather than overall recession, that is crucial to sub-annual moraine production. Our UAV data indicate that subannual squeeze moraines can be formed despite net re-advance, provided that there is retreat from the winter push moraine (Figs. 12 and 13). Strong overall recession from year to year is only a requirement for sub-annual moraine preservation (see Fig. 14). 
The influence of surface meltwater fluxes will be regulated by the englacial hydrological system, but crevasses, conduits and moulins can readily drain surface meltwater to the glacier bed and facilitate 'fast' englacial water transfer (cf. Fountain et al., 2005; Benn et al., 2009; Gulley et al., 2009). Recent instrumental and geophysical studies at Skálafellsjökull—an active temperate glacier with a similar landsystem signature to Fjallsjökull (cf. Evans and Orton, 2015; Chandler et al., 2016a, c) - have shown that it has a very low water-storage capacity and surface meltwater is rapidly transferred to the glacier bed via crevasses and moulins (Hart et al., 2015, 2019a, b). A combination of this efficient englacial drainage system and high meltwater inputs result in saturated subglacial tills throughout the melt season at Skálafellsjökull (cf. Hart et al., 2015, 2019b). The instrumental work has also recorded high water pressures during the entire melt season, which have been suggested to reflect an inefficient, distributed drainage system (Hart et al., 2019b; cf. Schoof, 2010). A similar scenario of high surface meltwater inputs, efficient englacial drainage and distributed (inefficient) subglacial drainage during the melt season at Fjallsjökull would result in high water pressures and saturated subglacial sediments. These conditions are conducive to till deformation due to the reduction in sediment shear strength (cf. Boulton and Hindmarsh, 1987; Benn and Evans, 1996; Boulton et al., 2001; Evans et al., 2006). Near the glacier margin, high porewater pressures and the presence of saturated, deforming subglacial sediments during the melt season would lead to till advection and ice-marginal squeezing, owing to the comparatively low basal shear stresses in the submarginal environment and their reduction towards the glacier margin (cf. Price, 1970; Evans and Hiemstra, 2005; Chandler et al., 2016a; Evans et al., 2016a). The rapid conveyance of surface meltwater through the englacial drainage system to the glacier bed could therefore be a factor contributing to icemarginal squeezing. 
Basal topography and drainage conditions are also likely to be important factors influencing the nature and frequency of moraine formation at Fjallsjökull. Most of the sub-annual moraines at the southern glacier margin are located on a reverse slope, and Fjallsjökull is actively retreating into a substantial overdeepening (cf. Magnússon et al., 2012; Dell et al., 2019) or, more specifically, down the adverse slope of a glacially-overridden ice-contact fan/ramp (cf. Evans et al., 2018b). This emerging subglacial topography locally impedes drainage, leading to highly saturated subglacial/submarginal sediments and high pore-water pressures. Combined with enhanced surface melting and increased meltwater fluxes to the glacier bed (see above), the poor drainage conditions imparted by the basal topography provide favourable conditions for ice-marginal squeezing (cf. Chandler et al., 2016a; Evans et al., 2016a). Indeed, recent retreat into subglacial overdeepenings, coupled with the development of full-depth crevassing and marginal pecten, has been recognised as a control on sawtooth and hairpin-shaped moraine formation at several Icelandic active temperate outlets, representing a temporal switch in the active temperate landsystem signature (Evans et al., 2016a, 2017, 2018c, 2019). Previously-identified sub-annual moraines at Skálafellsjökull are also associated with a reverse slope and impeded drainage (Chandler et al., 2016a). Thus, basal topography and drainage conditions appear to exert an important influence on the nature and frequency of moraine formation at active temperate glaciers in Iceland, especially where snout morphologies have changed to more divergent flow with stronger radial crevassing in response to overall thinning.

We suggest that sub-annual moraine formation at Fjallsjökull is a process-form regime linked to glacier retreat into an overdeepening during a period of elevated summer temperatures. These above-average temperatures drive enhanced glacier surface melt and meltwater flux to 
the bed, saturating the subglacial sediments and elevating porewater pressures. Abnormally intensive and prolonged rainfall events during the summer are also potentially significant by generating supraglacial runoff that is immediately and efficiently coupled with the subglacial environment, a relationship that requires further testing (cf. O'Neel et al., 2001; Vieli et al., 2004; Purdie et al. 2008). It is possible that high surface meltwater and rainfall inputs may be rapidly conveyed to the bed of Fjallsjökull by an efficient englacial drainage system (cf. Hart et al., 2015, 2019a, b), resulting in high water pressures and saturated subglacial sediments throughout the melt season. This situation may be exacerbated by poor drainage conditions imparted by the emerging basal topography. The resulting highly-saturated submarginal sediments and high porewater pressure in turn lead to submarginal deformation and icemarginal squeezing (cf. Price, 1970; Sharp, 1984; Evans and Hiemstra, 2005; Chandler et al., 2016a, and references therein). Strong glacier recession during the melt season (driven by above-average temperatures) enables melt-driven squeeze events to produce multiple moraines, hence the occurrence of recently formed sub-annual moraines at Fjallsjökull.

\subsection{Wider significance and implications}

The landsystem signatures of many active temperate glaciers in Iceland are characterised by the creation of increasingly complex, closely-spaced, sawtooth or hairpin-shaped moraine sequences over the past 30 years (e.g. Chandler et al., 2016a, b; Evans et al., 2016a, 2017, 2018c, 2019; Evans and Ewertowski, 2018). These moraines exhibit morphological characteristics that are very similar to those at Fjallsjökull, and they have also been associated with marginal-thickening till wedges (cf. Evans and Hiemstra, 2005; Evans et al., 2018a). It is possible that the sawtooth moraines at other Icelandic outlet glaciers may also (partly) represent sub-annual moraine formation during the current period of elevated temperatures. 
Even in areas where the number of moraines is equivalent to the time elapsed, these may not necessarily represent annual moraines, as is often assumed (cf. Chandler et al., 2016a, and references therein). Our repeat UAV surveys have demonstrated that (a) annual/winter readvances can obliterate moraines formed in the previous year and (b) sub-annual moraine formation can occur even during phases of net re-advance. In these cases, the number of moraines could still equate to the number of years (and thus appear to be annual moraines), despite the obliterative overlap of the moraine sequence (cf. Kirkbride and Winkler, 2012). We hypothesise that sub-annual moraine formation is a process-form regime that is characteristic of heavily radially-crevassed active temperate glacier margins that are thinning and undergoing divergent flow as they retreat into subglacial overdeepenings during periods of increased temperatures and glacier surface melting and runoff.

A corollary of this is that the spacing between individual minor/sawtooth moraines on Icelandic glacier forelands may not be a suitable geomorphological proxy for ice-marginal retreat, especially over the last $\sim 30$ years. Several studies in Iceland have equated moraine spacing with ice-marginal retreat and then utilised these to examine climatic drivers of glacier retreat (e.g. Bradwell, 2004a; Bradwell et al., 2013; Chandler et al., 2016a, c; Evans et al., 2019b). Our observations at Fjallsjökull indicate that moraine spacing may not necessarily equate to 'actual' ice-marginal retreat, even though studies have shown a general temporal correspondence between moraine spacing and ablation-season/summer temperature anomalies (e.g. Boulton, 1986; Bradwell, 2004a; Bradwell et al., 2013; Chandler et al., 2016a; Evans et al., 2019b). Rather, the minor/sawtooth moraine sequences in Iceland represent incomplete and modulated (or 'censored'; cf. Kirkbride and Winkler, 2012) records of various glacier submarginal and ice-marginal processes operating over seasonal cycles. Indeed, sub-annual moraine formation and subsequent 'censoring' of the moraine sequences 
could explain the low coefficients of determination $\left(r^{2}=0.39-0.56\right.$; Bradwell, 2004; Chandler et al., 2016a) reported in statistical analyses of 'annual' moraine spacing and summer temperature, despite very highly statistically significant $(p<0.001)$ relationships. Over multi-decadal and longer timescales, it is likely that the preservation potential of subannual squeeze moraines will be relatively low as a result of their low-relief forms.

Consequently, it is conceivable that only the larger, winter push moraines will be preserved in active temperate glacial landsystem signatures over geological timescales.

\section{6 | CONCLUSIONS}

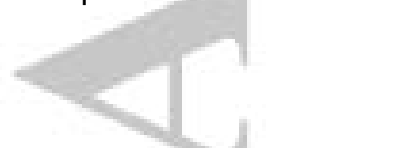

We examined a sequence of small recessional moraines ('minor moraines') at the southern margin of Fjallsjökull, an active temperate Icelandic glacier, using a combination of geomorphological mapping, sedimentological analysis, remote sensing, and repeat UAV surveys. The moraines were formed during the past $\sim 15$ years and have distinctive sawtooth or hairpin-shaped forms, with localised superimposition producing a complex spatial pattern. We recognised two distinct populations of moraines, namely a group of relatively prominent moraine ridges (mean height $\sim 1.2 \mathrm{~m}$ ) and a group of comparatively low-relief moraines (mean height $\sim 0.4 \mathrm{~m}$ ). These two groups often occur in sets/systems, comprising one pronounced outer ridge and several inset smaller moraines.

Our sedimentological investigations reveal that the moraines consist predominantly or entirely of subglacial traction tills. In some cases, the moraines also contain sorted sediments lenses/layers (e.g. massive or horizontally-bed sands, massive or laminated silts), interpreted as sediments originally deposited by meltwater in small submarginal/ice-marginal streams or ponds. The predominance of subglacial traction till and the internal architecture/structure of 
the exposures (e.g. the presence of tight anticlinal folds) indicates that the moraines were constructed by either (i) submarginal deformation and squeezing of subglacial tills, or (ii) icemarginal pushing of extruded subglacial tills (and proglacial sediments, in some cases). The latter process is responsible for the folds in some moraines, with ice-marginal advances leading to lateral compression of unfrozen extruded subglacial tills and proglacial sediments, ductile deformation and push moraine formation.

By examining remotely-sensed data $(2003,2012,2014)$ and repeat UAV imagery (20162019), we demonstrate that the processes of submarginal deformation, squeezing and icemarginal pushing have constructed multiple moraines per year (i.e. sub-annual moraines) at Fjallsjökull for most of the past $\sim 15$ years. To our knowledge, our repeat UAV imagery provides the first unequivocal evidence for sub-annual moraine formation. The UAV surveys also reveal that moraines were formed sub-annually along sectors that experienced overall readvance in three consecutive years (2016-2017, 2017-2018, and 2018-2019). Sub-annual moraines formed during the previous year were superimposed (the outer ridge) or obliterated entirely by these localised re-advances.

This high-frequency (sub-annual) moraine formation is argued to occur by a seasonal cycle of glacier submarginal and ice-marginal processes: (i) submarginal deformation and icemarginal squeezing are initiated in the melt season due to influxes of meltwater to the glacier bed, leading to the extrusion of subglacial tills and squeeze moraine formation by late summer; (ii) during the subsequent winter re-advance, extruded subglacial sediments/squeeze moraines are subject to pushing, resulting in lateral compression and push moraine construction; and (iii) influxes of surface meltwater or rainfall to the bed and strong glacier 
recession during the following melt season result in melt-driven squeezing and the formation of multiple, inset squeeze moraines.

We suggest that the development of this process-form regime is due to a combination of elevated temperatures, high surface meltwater fluxes to the bed, and emerging basal topography (a depositional overdeepening). These factors result in highly saturated subglacial till and high porewater pressures, which induces submarginal deformation and ice-marginal squeezing during the melt season. Strong glacier recession during the summer, driven by above-average temperatures, allows several inset squeeze moraines to be emplaced. This process-form regime may be characteristic of thinning active temperate glaciers with increasingly divergent marginal flow that are receding into subglacial overdeepenings during phases of elevated temperatures, especially where their englacial drainage systems allow efficient transfer of surface meltwater to the glacier bed.

\section{ACKNOWLEDGEMENTS}

Fieldwork was supported by grants from the British Society for Geomorphology and the Geologists' Association New Researchers Award, which are hereby gratefully acknowledged. Regína Hreinsdóttir and Helga Árnadóttir (both Vatnajökull National Park) are thanked for granting permission to undertake fieldwork and UAV surveying at Fjallsjökull; Tómas Jóhannesson is thanked for kindly provided access to the Icelandic Meteorological Office's LiDAR data. BMPC is grateful to Sven Lukas and Cianna Wyshnytzky for discussions of (sub)annual moraines. We thank two anonymous reviewers and the Associate Editor for comments that helped to improve the clarity of this paper. 


\section{DATA AVAILABILITY STATEMENT}

The datasets used and analysed during the current study are available from the corresponding author upon reasonable request.

\section{CONFLICT OF INTEREST STATEMENT}

The authors declare no conflict of interest.

\section{SUPPORTING INFORMATION}

Additional supporting information may be found online in the Supporting Information section at the end of the article.

Supporting Information 1. Description of UAV surveying and SfM processing methods.

\section{REFERENCES}

Andersen, J. L., \& Sollid, J. L. (1971). Glacial Chronology and Glacial Geomorphology in the Marginal Zones of the Glaciers, Midtdalsbreen and Nigardsbreen, South Norway. Norsk Geografisk Tidsskrift - Norwegian Journal of Geography, 25, 1-38.

Andrews, J. T., \& Smithson, B. B. (1966). Till Fabrics of the Cross-Valley Moraines of North-Central Baffin Island, Northwest Territories, Canada. Geological Society of America Bulletin, 77, 271-290.

Beedle, M. J., Menounos, B., Luckman, B. H., \& Wheate, R. (2009). Annual push moraines as climate proxy. Geophysical Research Letters, 36, L20501.

Benediktsson, Í. Ö., Jónsson, S. A., Schomacker, A., Johnson, M. D., Ingólfsson, Ó., Zoet, L., Iverson, N. R., \& Stötter, J. (2016). Progressive formation of modern drumlins at Múlajökull, Iceland: stratigraphical and morphological evidence. Boreas, 45, 567583.

Benn, D. I. (1994). Fluted moraine formation and till genesis below a temperate glacier: Slettmarkbreen, Jotunheimen, Norway. Sedimentology, 41, 279-292. 
Benn, D. I., \& Ballantyne, C. K. (1993). The description and representation of particle shape. Earth Surface Processes and Landforms, 18, 665-672.

Benn, D. I., \& Ballantyne, C. K. (1994). Reconstructing the transport history of glacigenic sediments: a new approach based on the co-variance of clast shape indices. Sedimentary Geology, 91, 215-227.

Benn, D.I. \& Evans, D.J.A. (2010). Glaciers and Glaciation. Hodder Education, London.

Benn, D. I., Gulley, J., Luckman, A., Adamek, A., \& Glowacki, P. S. (2009). Englacial drainage systems formed by hydrologically driven crevasse propagation. Journal of Glaciology, 55(191), 513-523.

Birnie, R. V. (1977). A snow-bank push mechanism for the formation of some 'annual' moraine ridges. Journal of Glaciology, 78, 77-85.

Boulton, G. S. (1976). The origin of glacially fluted surfaces - observations and theory. Journal of Glaciology, 17, 287-309.

Boulton, G. S. (1978). Boulder shapes and grain-size distributions of debris as indicators of transport paths through a glacier and till genesis. Sedimentology, 25, 773-799.

Boulton, G. S. (1986). Push-moraines and glacier-contact fans in marine and terrestrial environments. Sedimentology, 33, 677-698.

Boulton, G. S. (1987). A theory of drumlin formation by subglacial deformation. In: J. Rose, \& J. Menzies (Eds.), Drumlin Symposium (pp. 25-80). Rotterdam: Balkema.

Boulton, G. S., \& Dobbie, K. E. (1998). Slow flow of granular aggregates: the deformation of sediments beneath glaciers. Philosophical Transactions of the Royal Society A, 356 (1747), 2713-2745.

Boulton, G. S., \& Hindmarsh, R. C. A. (1987). Sediment deformation beneath glaciers: rheology and geological consequences. Journal of Geophysical Research: Solid Earth, 92, 9059-9082.

Boulton, G. S., Dobbie, K.E., \& Zatsepin, S. (2001). Sediment deformation beneath glaciers and its coupling to the subglacial hydraulic system. Quaternary International, 86, 328.

Bradwell, T. (2004a). Annual Moraines and Summer Temperatures at Lambatungnajökull, Iceland. Arctic, Antarctic and Alpine Research, 36, 502-508.

Bradwell, T. (2004b). Lichenometric dating in southeast Iceland: the size-frequency approach. Geografiska Annaler, 86A, 31-41.

Bradwell, T., Sigurdsson, O., \& Everest, J. (2013). Recent, very rapid retreat of a temperate glacier in SE Iceland. Boreas, 42, 959-973.

This article is protected by copyright. All rights reserved. 
Brasington, J., Langham, J., \& Rumsby, B. (2003). Methodological sensitivity of morphometric estimates of coarse fluvial sediment transport. Geomorphology, 53(34), 299-316.

Brook, M. S., \& Lukas, S. (2012). A revised approach to discriminating sediment transport histories in glacigenic sediments in a temperate alpine environment: a case study from Fox Glacier, New Zealand. Earth Surface Processes and Landforms, 37, 895-900.

Chandler, B. M. P., Evans, D. J. A., \& Roberts, D. H. (2016a). Characteristics of recessional moraines at a temperate glacier in SE Iceland: Insights into patterns, rates and drivers of glacier retreat. Quaternary Science Reviews, 135, 171-205.

Chandler, B. M. P., Evans, D. J. A., \& Roberts, D. H. (2016b). Recent retreat at a temperate Icelandic glacier in the context of the last $\sim 80$ years of climate change in the North Atlantic region. arktos, 2, 24.

Chandler, B. M. P., Evans, D. J. A., Roberts, D. H., Ewertowski, M., \& Clayton, A. I. (2016c). Glacial geomorphology of the Skálafellsjökull foreland, Iceland: A case study of 'annual' moraines. Journal of Maps, 12, 904-916.

Chandler, B. M. P., Lovell, H., Boston, C. M., Lukas, S., Barr, I. D., Benediktsson, Í. Ö., Benn, D. I., Clark, C. D., Darvill, C. M., Evans, D. J. A., Ewertowski, M. W., Loibl, D., Margold, M., Otto, J. -C., Roberts, D. H., Stokes, C. R., Storrar, R. D., \& Stroeven, A. P. (2018). Glacial geomorphological mapping: A review of approaches and frameworks for best practice. Earth-Science Reviews, 185, 806-846.

Collinson, J. D., Mountney, N. P., \& Thompson, D. B. (2006). Sedimentary Structures. Harpenden: Terra Publishing.

Dell, R., Carr, R., Phillips, E., \& Russell, A. J. (2019). Response of glacier flow and structure to proglacial lake development and climate at Fjallsjökull, south-east Iceland. Journal of Glaciology, 65, 321-336.

Evans, D. J. A. (2000). A gravel outwash/deformation till continuum, Skalafellsjokull, Iceland. Geografiska Annaler, 82A, 499-512.

Evans, D. J. A. (2003). Ice-marginal terrestrial landsystems: active temperate glacier margins. In: D.J.A. Evans (Ed.), Glacial Landsystems (pp. 12-43). London: Arnold.

Evans, D. J. A. (2009). Glacial Geomorphology at Glasgow. Scottish Geographical Journal, $125,285-320$.

Evans, D. J. A. (2010). Controlled moraine development and debris transport pathways in polythermal plateau icefields: examples from Tungnafellsjökull, Iceland. Earth Surface Processes and Landforms, 35, 1430-1444.

This article is protected by copyright. All rights reserved. 
Evans, D. J. A. (2018). Till: A Glacial Process Sedimentology. The Cryosphere Science Series. Chichester: Wiley Blackwell.

Evans, D. J. A., \& Benn, D. I. (Eds.). (2004). A Practical Guide to the Study of Glacial Sediments. London: Arnold.

Evans, D. J. A., Ewertowski, M. W. (2018). The glacial landsystem of the Fláajökull north lobe. In: D.J.A. Evans (Ed.), Glacial Landsystems of Southeast Iceland - Quaternary Applications: Field Guide (pp. 243-258). London: Quaternary Research Association.

Evans, D. J. A., \& Hiemstra, J. F. (2005). Till deposition by glacier submarginal, incremental thickening. Earth Surface Processes and Landforms, 30, 1633-1662.

Evans, D. J. A., \& Twigg, D. R. (2002). The active temperate glacial landsystem: a model based on Breiðamerkurjökull and Fjallsjökull, Iceland. Quaternary Science Reviews, $21,2143-2177$.

Evans, D. J. A., Phillips, E. R., Hiemstra, J. F., \& Auton, C. A. (2006). Subglacial till: Formation, sedimentary characteristics and classification. Earth-Science Reviews, 78, $115-176$.

Evans, D.J.A., Shand, M., \& Petrie, G. (2009). Maps of the snout and proglacial landforms of Fjallsjökull, Iceland (1945, 1965, 1998). Scottish Geographical Journal, 125, 304312.

Evans, D. J. A., Ewertowski, M., \& Orton, C. (2016a). Fláajökull (north lobe), Iceland: active temperate piedmont lobe glacial landsystem. Journal of Maps, 12, 777-789.

Evans, D. J. A., Roberts, D. H., \& Evans, S. C. (2016b). Multiple subglacial till deposition: A modern exemplar for Quaternary palaeoglaciology. Quaternary Science Reviews, 145, $183-203$.

Evans, D. J. A., Ewertowski, M., \& Orton, C. (2017). Skaftafellsjökull, Iceland: glacial geomorphology recording glacier recession since the Little Ice Age. Journal of Maps, $13,358-368$.

Evans, D. J. A., Roberts, D. H., Hiemstra, J. F., Nye, K. M., Wright, H., \& Steer, A. (2018a). Submarginal debris transport and till formation in active temperate glacier systems: The southeast Iceland type locality. Quaternary Science Reviews, 195, 72-108.

Evans, D. J. A., Ewertowski, M., \& Roberts, D. H. (2018b). Glacial landsystem development at Fjallsjökull. In, Evans D.J.A. (Ed.), Glacial Landsystems of Southeast Iceland: Quaternary Applications - Field Guide (pp. 224-241). London: Quaternary Research Association. 
Evans, D. J. A., Ewertowski, M., Orton, C., \& Graham, D. J. (2018c). The glacial geomorphology of the ice cap piedmont lobe landsystem of East Myrdalsjokull, Iceland. Geosciences, 8, 194.

Evans, D. J. A., Ewertowski, M. W., \& Orton, C. (2019a). The glacial landsystem of Hoffellsjökull, SE Iceland: contrasting geomorphological signatures of active temperate glacier recession driven by ice lobe and bed morphology. Geografiska Annaler, 101A, 249-276.

Evans, D. J. A., Guðmundsson, S., Vautrey, J. L., Fearnyough, K., \& Southworth, W. G. (2019b). Testing lichenometric techniques in the production of a new growth-rate (curve) for the Breiðamerkurjökull foreland, Iceland, and the analysis of potential climatic drivers of glacier recession, Geografiska Annaler, 101A, 225-248.

Ewertowski, M. W, Tomczyk, A. M, Evans, D. J. A., Roberts, D. H, \& Ewertowski, W. (2019). Operational Framework for Rapid, Very-high Resolution Mapping of Glacial Geomorphology Using Low-cost Unmanned Aerial Vehicles and Structure-fromMotion Approach. Remote Sensing, 11, 65.

Eyles, N., Eyles, C. H., \& Miall, A. D. (1983). Lithofacies types and vertical profile models. An alternative approach to the description and environmental interpretation of glacial diamict and diamictite sequences. Sedimentology, 30, 393-410.

Eypórsson, J. (1935). On the variations of glaciers in Iceland. Some studies made in 1931. Geografiska Annaler, 17, 121-137.

Eypórsson, J. (1963). Variation of Iceland glaciers 1931-1960. Jökull, 13, 31-33.

Fountain, A. G., Schlicting, R. B., Jacobel, R. W., \& Jansson, P. (2005). Fractures as main pathways of water flow in temperate glaciers. Nature, 433, 618-621.

Gordon, J. E., \& Timmis, R. J. (1992). Glacier fluctuations on South Georgia during the 1970s and early 1980s. Antarctic Science, 4(2), 215-226.

Graham, D. J., \& Midgley, N. G. (2000). Graphical representation of particle shape using triangular diagrams: an Excel spreadsheet method. Earth Surface Processes and Landforms, 25, 1473-1477.

Gulley, J. D., Benn, D. I., Screaton, E., \& Martin, J. (2009). Mechanisms of englacial conduit formation and their implications for subglacial recharge. Quaternary Science Reviews, 28, 1984-1999.

Ham, N. R., \& Attig, J. W. (2001). Minor end moraines of the Wisconsin Valley Lobe, northcentral Wisconsin, USA. Boreas, 30, 31-41. 
Harris, C., \& Bothamley, K. (1984). Englacial deltaic sediments as evidence for basal freezing and marginal shearing, Leirbreen, southeastern Norway. Journal of Glaciology, 30, 30-34.

Hart, J. K., Rose, K. C., Clayton, A., \& Martinez, K. (2015). Englacial and subglacial water flow at Skálafellsjökull, Iceland derived from ground penetrating radar, in situ Glacsweb probe and borehole water level measurements. Earth Surface Processes and Landforms, 40, 2071-2083.

Hart, J. K., Martinez, K., Basford, P. J., Clayton, A. I., Bragg, G. M., Ward, T., \& Young, D. S. (2019a). Surface melt-driven seasonal behaviour (englacial and subglacial) from a soft-bedded temperate glacier recorded by in situ wireless probes. Earth Surface Processes and Landforms.

Hart, J. K., Martinez, K., Basford, P. J., Clayton, A. I., Robson, B. A., Young, D. S. (2019b). Surface melt driven summer diurnal and winter multi-day stick-slip motion and till sedimentology. Nature Communications, 10, 1599.

Hiemstra, J. F., Matthews, J. A., Evans, D. J. A., \& Owen, G. (2015). Sediment fingerprinting and the mode of formation of singular and composite annual moraine ridges at two glacier margins, Jotunheimen, southern Norway. The Holocene, 25, 1772-1785.

James, M. R., Robson, S., d'Oleire-Oltmanns, S., \& Niethammer U. (2017a). Optimising UAV topographic surveys processed with structure-from-motion: ground control quality, quantity and bundle adjustment. Geomorphology, 280, 51-66.

James, M. R., Robson, S., \& Smith, M. W. (2017b). 3-D uncertainty-based topographic change detection with structure-from-motion photogrammetry: precision maps for ground control and directly georeferenced surveys. Earth Surface Processes and Landforms, 42, 1769-1788.

Jóhannesson, T., Björnsson, H., Magnússon, E., Guðmundsson, S., Pálsson, F., Sigurðsson, O., Thorsteinsson, T., \& Berthier, E. (2013). Ice-volume changes, bias estimation of mass-balance measurements and changes in subglacial lakes derived by lidar mapping of the surface of Icelandic glaciers. Annals of Glaciology, 54(63), 63-74.

Jónsson, S. A., Benediktsson, Í. Ö., Ingólfsson, Ó., Schomacker, A., Bergsdóttir, H. L., Jacobson, W. R., \& Linderson, H. (2016). Submarginal drumlin formation and late Holocene history of Fláajökull, southeast Iceland. Annals of Glaciology, 57, 128-141.

Karlén, W., \& Denton, G. H. (1975). Holocene glacial variations in Sarek National Park, northern Sweden. Boreas, 5, 25-56.

This article is protected by copyright. All rights reserved. 
Kirkbride, M. P., \& Winkler, S. (2012). Correlation of Late Quaternary moraines: impact of climate variability, glacier response, and chronological resolution. Quaternary Science Reviews, 46, 1-29.

Krüger, J. (1993). Moraine-ridge formation along a stationary ice front in Iceland. Boreas, $22,101-109$.

Krüger, J. (1994). Glacial processes, sediments, landforms, and stratigraphy in the terminus region of Myrdalsjökull, Iceland. Folia Geographica Danica, 21, 1-233.

Krüger, J. (1995). Origin, chronology and climatological significance of annual-moraine ridges at Myrdalsjökull, Iceland. The Holocene, 5, 420-427.

Krüger, J. (1996). Moraine ridges formed from subglacial frozen-on sediment slabs and their differentiation from push moraines. Boreas, 25, 57-64.

Lawson, D. E. (1982). Mobilization, Movement and Deposition of Active Subaerial Sediment Flows, Matanuska Glacier,Alaska. The Journal of Geology, 90, 279-300.

Luckman, B. H. (2017). Glacier Landscapes in the Canadian Rockies. In: O. Slaymaker (Ed.), Landscapes and Landforms of Western Canada (pp. 241-255) Springer International Publishing.

Lukas, S. (2005). A test of the englacial thrusting hypothesis of 'hummocky' moraine formation: case studies from the northwest Highlands, Scotland. Boreas, 34, 287-307.

Lukas, S. (2007). Early-Holocene glacier fluctuations in Krundalen, south central Norway: palaeoglacier dynamics and palaeoclimate. The Holocene, 17, 585-598.

Lukas, S. (2012). Processes of annual moraine formation at a temperate alpine valley glacier: insights into glacier dynamics and climatic controls. Boreas, 41, 463-480.

Lukas, S., Benn, D. I., Boston, C. M., Brook, M., Coray, S., Evans, D. J. A., Graf, A., Kellerer-Pirklbauer, A., Kirkbride, M. P., Krabbendam, M., Lovell, H., Machiedo, M., Mills, S. C., Nye, K., Reinardy, B. T. I., Ross, F. H., \& Signer, M. (2013). Clast shape analysis and clast transport paths in glacial environments: A critical review of methods and the role of lithology. Earth-Science Reviews, 121, 96-116.

Magnússon, E., Pálsson, F., Björnsson, H., \& Guðmundsson, S. (2012). Removing the ice cap of Öraefajokull central volcano, SE Iceland: Mapping and interpretation of bedrock topography, ice volumes, subglacial troughs and implications for hazards assessments. Jökull, 62, 131-150.

Maizels, J.K. (1993). Lithofacies variations within sandur deposits: the role of runoff regime, flow dynamics and sediment supply characteristics. Sedimentary Geology, 85, 299325.

This article is protected by copyright. All rights reserved. 
Marren, P.M. (2002). Glacier margin fluctuations, Skaftafellsjökull, Iceland: Implications for sandur evolution. Boreas, 31, 75-81.

Marren, P.M. (2005). Magnitude and frequency in proglacial rivers: A geomorphological and sedimentological perspective. Earth Science Reviews, 70, 203-251.

Matthews, J. A., Cornish, R., \& Shakesby, R. A. (1979). 'Saw-tooth' moraines in front of Bødalsbreen, southern Norway. Journal of Glaciology, 22, 535-546.

Matthews, J. A., McCarroll, D., \& Shakesby, R. A. (1995). Contemporary terminal-moraine ridge formation at a temperate glacier: Styggedalsbreen, Jotunheimen, southern Norway. Boreas, 24, 129-139.

O’Neel, S., Echelmeyer, K.A., \& Motyka, R.J. (2001). Short-term flow dynamics of a retreating tidewater glacier: LeConte Glacier, Alaska, U.S.A. Journal of Glaciology, $47,567-578$.

Price, R. J. (1970). Moraines at Fjallsjökull, Iceland. Arctic and Alpine Research, 2, 27-42.

Purdie, H.L., Brook, M.S., \& Fuller, I.C. (2008). Seasonal Variation in Ablation and Surface Velocity on a Temperate Maritime Glacier: Fox Glacier, New Zealand. Arctic, Antarctic and Alpine Research, 40, 140-147.

Reinardy, B. T. I., Leighton, I., \& Marx, P. J. (2013). Glacier thermal regime linked to processes of annual moraine formation at Midtdalsbreen, southern Norway. Boreas, 42, 896-911.

Roberts, D. H. (1995). The development of criteria to distinguish glaciotectonic and glaciomarine sedimentary environments. Unpublished $\mathrm{PhD}$ thesis, University of Southampton.

Rose, J., Whiteman, C. A., Lee, J., Branch, N. P., Harkness, D. D., \& Walden, J. (1997). Midand late-Holocene vegetation, surface weathering and glaciation, Fjallsjokull, southeast Iceland. The Holocene, 7, 457-471.

Ryan, J. C., Hubbard, A. L., Box, J. E., Todd, J., Christoffersen, P., Carr, J. R., Holt, T. O., \& Snooke, N. (2015). UAV photogrammetry and structure from motion to assess calving dynamics at Store Glacier, a large outlet draining the Greenland ice sheet. The Cryosphere, 9, 1-11.

Schomacker, A., Benediktsson, Í. Ö., Ingólfsson, Ó., Friis, B., Korsgaard, N. J., Kjær, K., \& Keiding, J. K. (2012). Late Holocene and modern glacier changes in the marginal zone of Sólheimajökull, South Iceland. Jökull, 62, 111-130.

Schoof, C. (2010). Ice-sheet acceleration driven by melt supply variability. Nature, 468(7325), 803-806.

This article is protected by copyright. All rights reserved. 
Sharp, M. (1984). Annual moraine ridges at Skálafellsjökull, south-east Iceland. Journal of Glaciology, 30, 82-93.

Sigurðsson, O., Jónsson, T., \& Jóhannesson, T. (2007). Relation between glacier-termini variations and summer temperature in Iceland since 1930. Annals of Glaciology, 46, $170-176$.

Spedding, N., \& Evans, D. J. A. (2002). Sediments and landforms at Kviárjökull, southeast Iceland: a reappraisal of the glaciated valley landsystem. Sedimentary Geology, 149, $21-42$.

Sutherland, J. L., Carrivick, J. L., Evans, D. J. A., Shulmeister, J., \& Quincey, D. J. (2019). The Tekapo Glacier, New Zealand, during the Last Glacial Maximum: An active temperate glacier influenced by intermittent surge activity. Geomorphology, 343, $183-210$.

Thórarinsson, S. (1943). Vatnajokull. Scientific Results of the Swedish-Icelandic Investigations 1936-37-38. Chapter XI. Geografiska Annaler, 25, 1-54.

Thórarinsson, S. (1967). Washboard moraines in front of Skeiðarárjökull. Jökull, 17, 311312.

Vieli, A., Jania, J., Blatter, H., \& Funk, M. (2004). Short-term velocity variations on Hansbreen, a tidewater glacier in Spitsbergen. Journal of Glaciology, 50, 389-398.

Westoby, M. J., Brasington, J., Glasser, N. F., Hambrey, M. J., \& Reynolds, J. M. (2012). 'Structure-from-Motion' photogrammetry: A low-cost, effective tool for geoscience applications. Geomorphology, 179, 300-314.

Wheaton, J. M., Brasington, J., Darby, S. E., Merz, J., Pasternack, G. B., Sear, D., \& Vericat, D. (2010). Linking geomorphic changes to salmonid habitat at a scale relevant to fish. River Research and Applications, 26(4), 469-486.

Winkler, S., \& Matthews, J. A. (2010). Observations on terminal moraine-ridge formation during recent advances of southern Norwegian glaciers. Geomorphology, 116, 87106.

Worsley, P. (1974). Recent 'annual' moraine ridges at Austre Okstindbreen, Okstindan, North Norway. Journal of Glaciology, 13, 265-277.

Wyshnytzky, C. E. (2017). On the mechanisms of minor moraine formation in high-mountain environments of the European Alps (Unpublished $\mathrm{PhD}$ thesis). Queen Mary University of London, London.

This article is protected by copyright. All rights reserved. 
Table 1. Summary of the UAV survey parameters and associated processing errors. Total (XYZ) root mean square errors (RMSEs), mean errors and standard deviation (SD) of error are reported relative to internal control points and external check points.

\begin{tabular}{|c|c|c|c|c|}
\hline & \multicolumn{4}{|c|}{ Survey year } \\
\hline & 2016 & 2017 & 2018 & 2019 \\
\hline Survey date & $\begin{array}{r}\text { September } \\
2016\end{array}$ & $\begin{array}{r}\text { September } \\
2017\end{array}$ & $\begin{array}{r}\text { August } \\
2018 \\
\end{array}$ & May 2019 \\
\hline Camera model & FC300S & FC6310 & FC6310 & FC300X \\
\hline Survey area $\left(\mathrm{km}^{2}\right)$ & 0.480 & 0.312 & 0.419 & 0.548 \\
\hline Average flight height (m) & 71.8 & 86.0 & 89.8 & 86.6 \\
\hline No. of images & 515 & 642 & 706 & 449 \\
\hline $\begin{array}{l}\text { Ground sampled distance } \\
(\mathrm{cm} / \mathrm{pix})\end{array}$ & 2.70 & 2.17 & 2.25 & 3.28 \\
\hline No. of control points & 19 & 19 & 28 & 31 \\
\hline No. of check points & 9 & 9 & 12 & 22 \\
\hline Total internal RMSE (cm) & 9.46 & 10.27 & 13.75 & 4.56 \\
\hline Total external RMSE (cm) & 17.07 & 12.30 & 17.32 & 5.79 \\
\hline $\begin{array}{l}\text { Total internal mean error } \\
(\mathrm{cm})\end{array}$ & 8.89 & 9.17 & 11.13 & 2.12 \\
\hline $\begin{array}{l}\text { Total external mean error } \\
(\mathrm{cm})\end{array}$ & 15.21 & 11.78 & 16.26 & 1.92 \\
\hline $\begin{array}{l}\text { Total internal SD of error } \\
(\mathrm{cm})\end{array}$ & 3.33 & 4.75 & 8.22 & 5.01 \\
\hline $\begin{array}{l}\text { Total external SD of error } \\
(\mathrm{cm})\end{array}$ & 8.22 & 3.78 & 6.24 & 6.08 \\
\hline
\end{tabular}




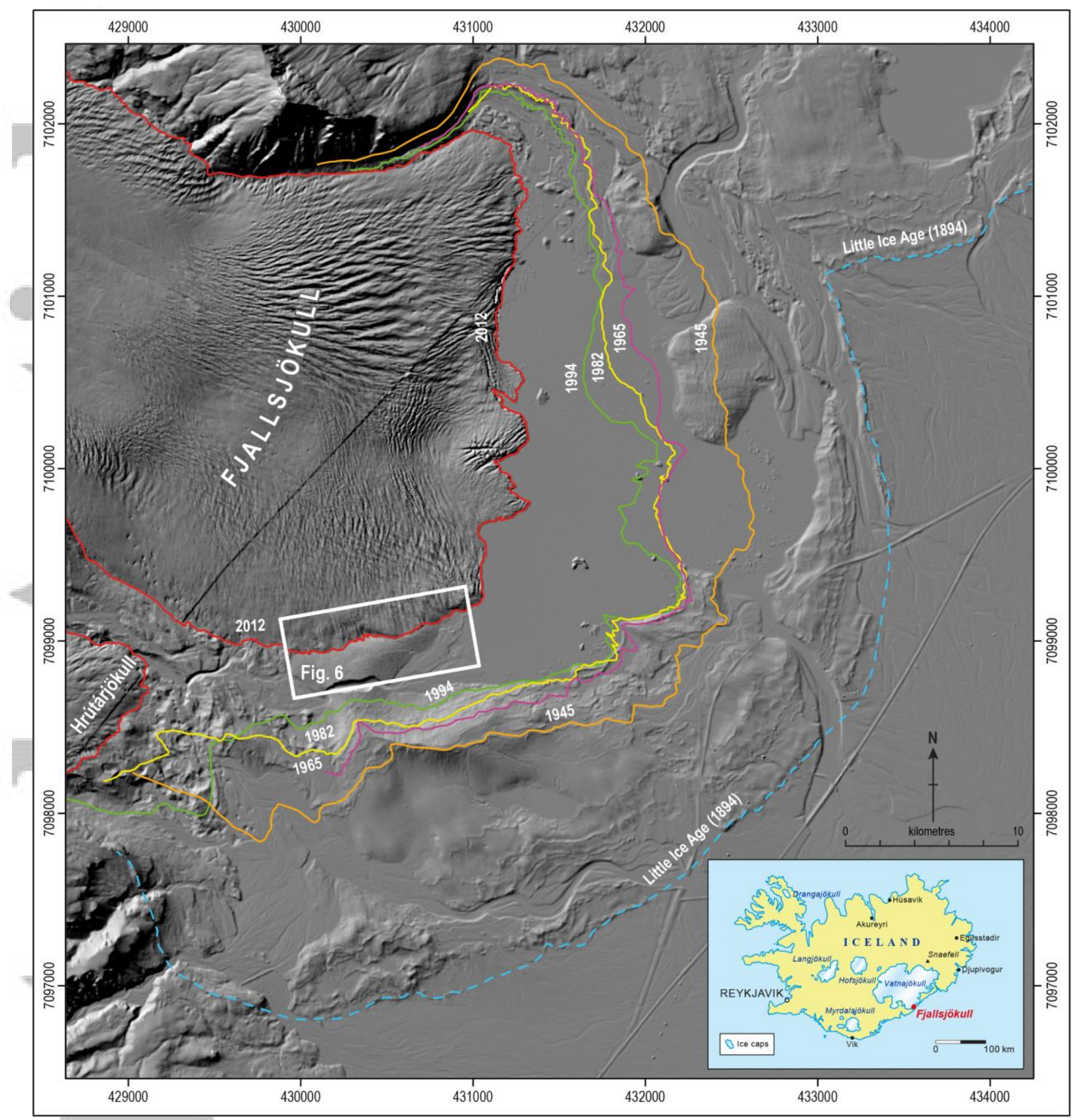

Fig. 1. Location and overview of the Fjallsjökull foreland, southeast Iceland. The primary study area and location of our high-resolution geomorphological map of the Fjallsjökull minor moraines (see Fig. 6) are shown by the white frame. Selected former positions of the glacier margin are indicated, based on aerial photographs acquired from Landmælingar Íslands. The background hillshade relief model was produced from LiDAR point-cloud data provided by the Icelandic Meteorological Office. The historical Little Ice Age date is based on archival data, as reported in Thórarinsson (1943).

This article is protected by copyright. All rights reserved. 


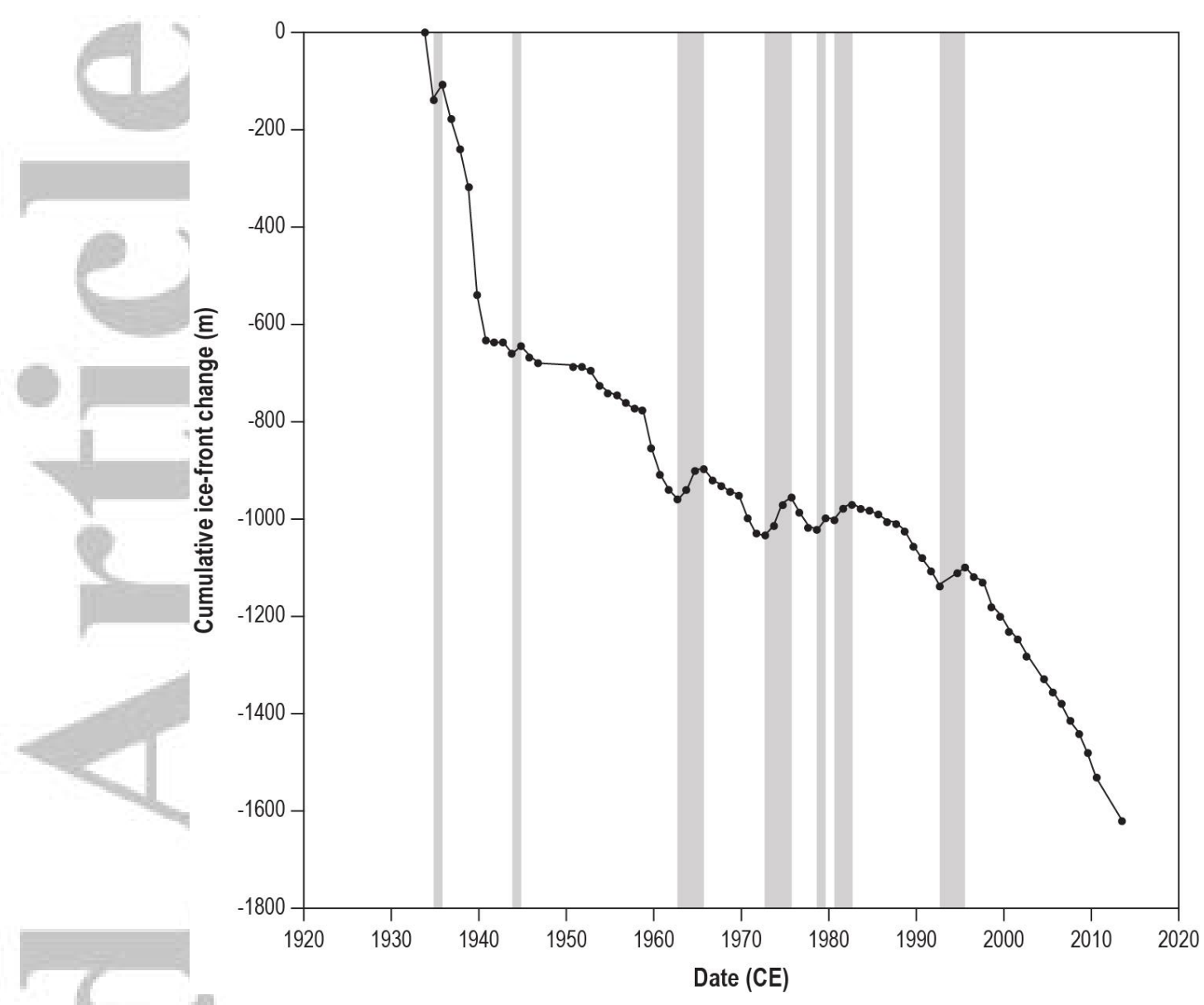

Fig. 2. Cumulative ice-front change at the southern Fjallsjökull, with grey shading indicating periods of re-advance. Based on ice-front measurements along the 'Gamlasel' transect, obtained from the Icelandic Glaciological Society database (http://spordakost.jorfi.is/index.shtml?lang=eng). 


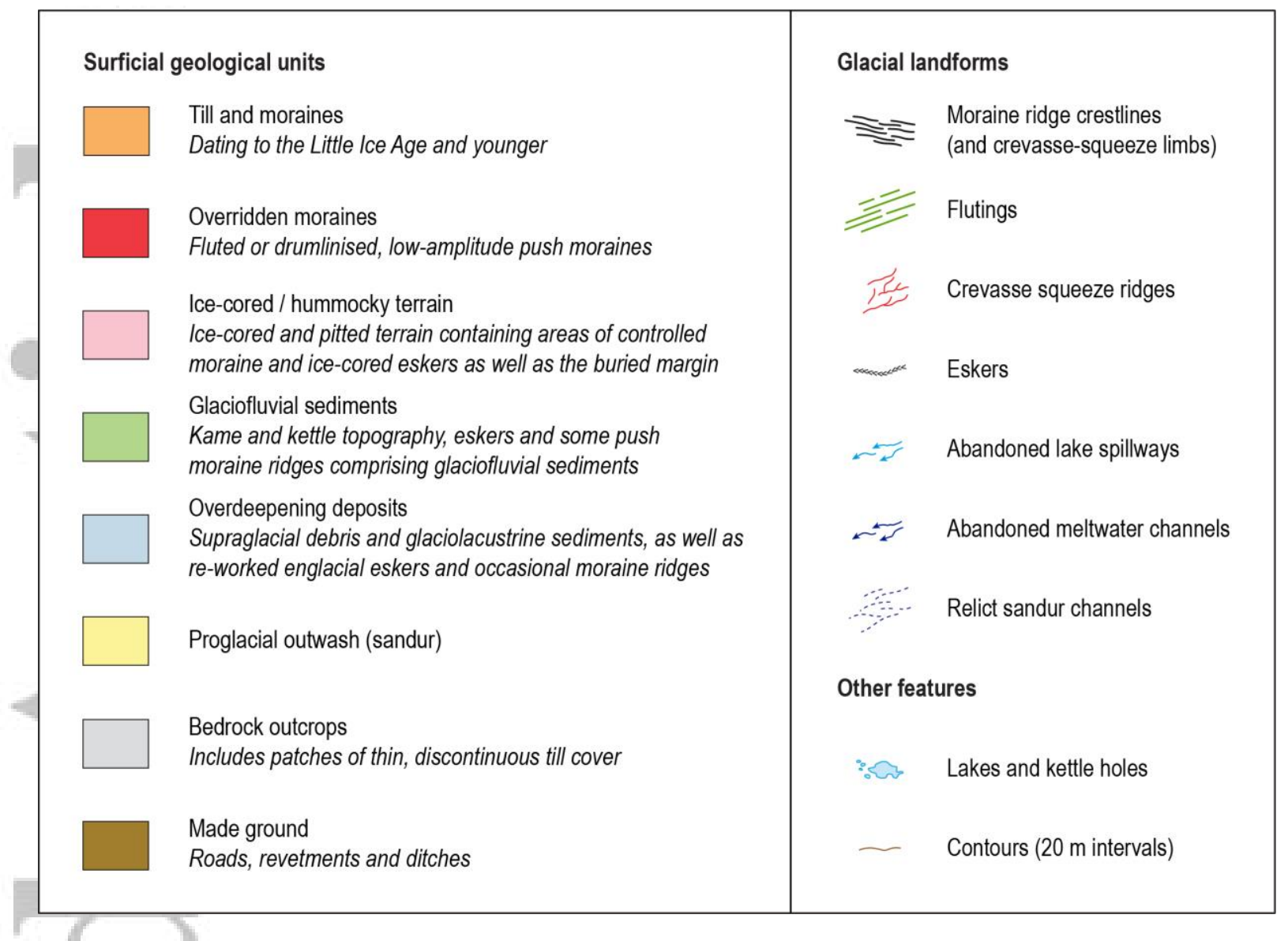

Fig. 3. Legend for all the glacial geomorphological maps (Figs. 5 and 6) and map extracts (in Figs. 11 and 13) presented in this paper. The symbology for the surficial geological units and glacial landforms follows the scheme widely applied to Icelandic glacier forelands (see Evans, 2009). 


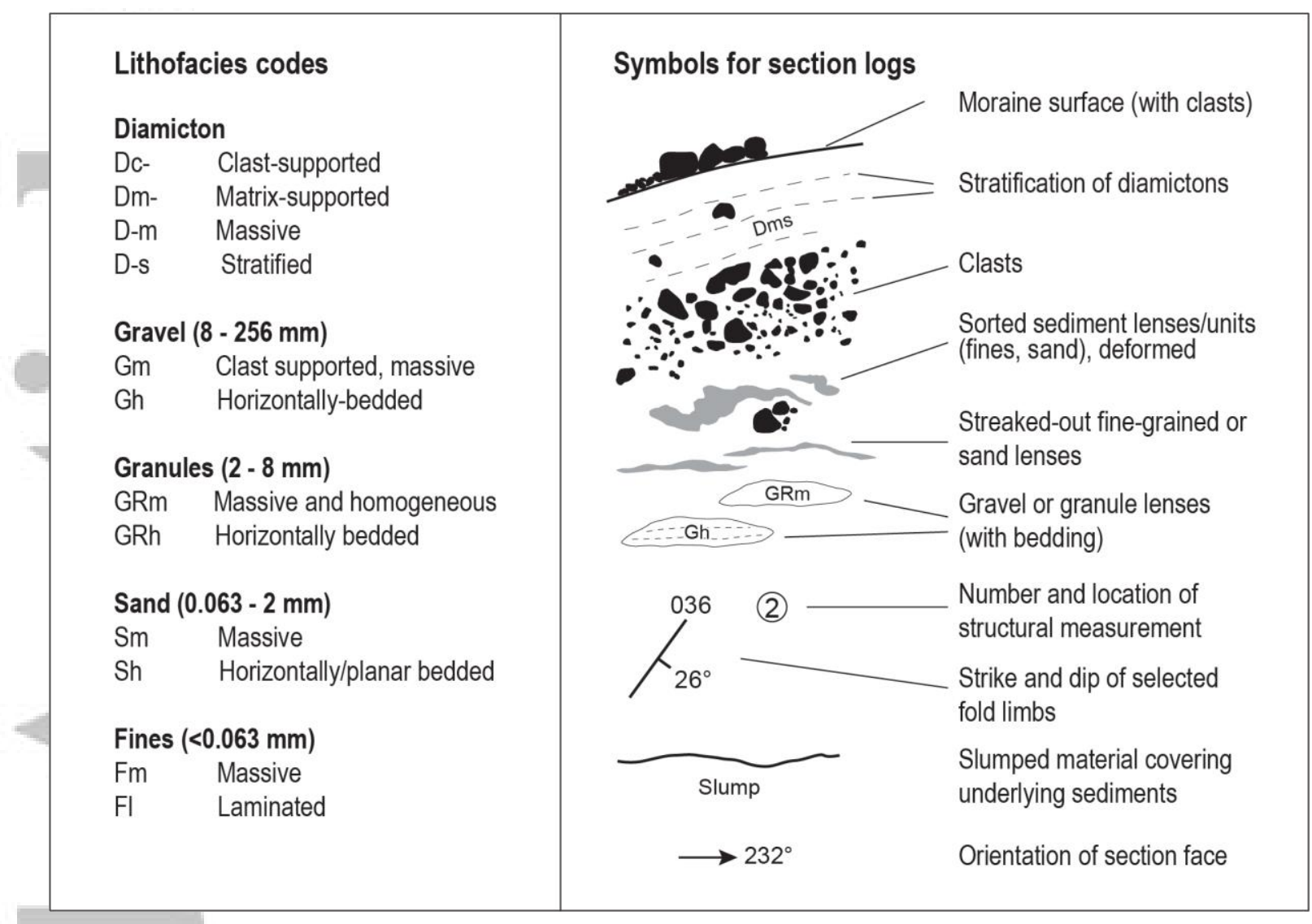

Fig. 4. Lithofacies codes and symbols used on the section logs presented in this paper. The lithofacies codes are adapted from Eyles et al. (1983) and Benn and Evans (2010). The symbology is after Lukas (2012) and Chandler et al. (2016a). 


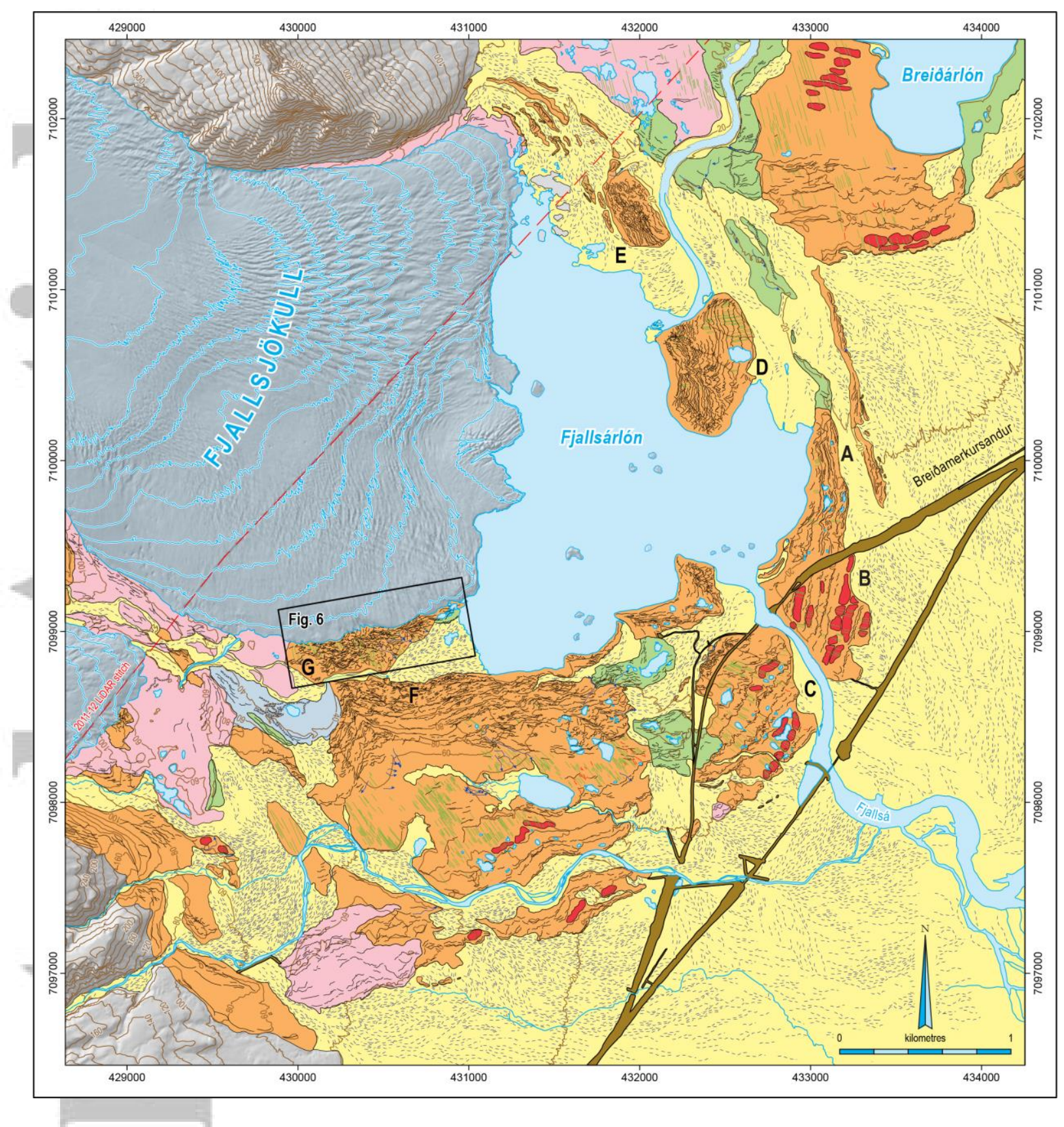

Fig. 5. Glacial geomorphological and surficial geological map of the Fjallsjökull foreland, based on LiDAR data (2011 and 2012) as well as field mapping and aerial photograph interpretation. Data from 2011 and 2012 were stitched together (indicated by the red dashed line) to provide a composite DEM of the entire foreland. The location of our high-resolution UAV mapping is shown by the black frame; the letters indicate moraine assemblages referred to in the text. For key, see Fig. 3. 


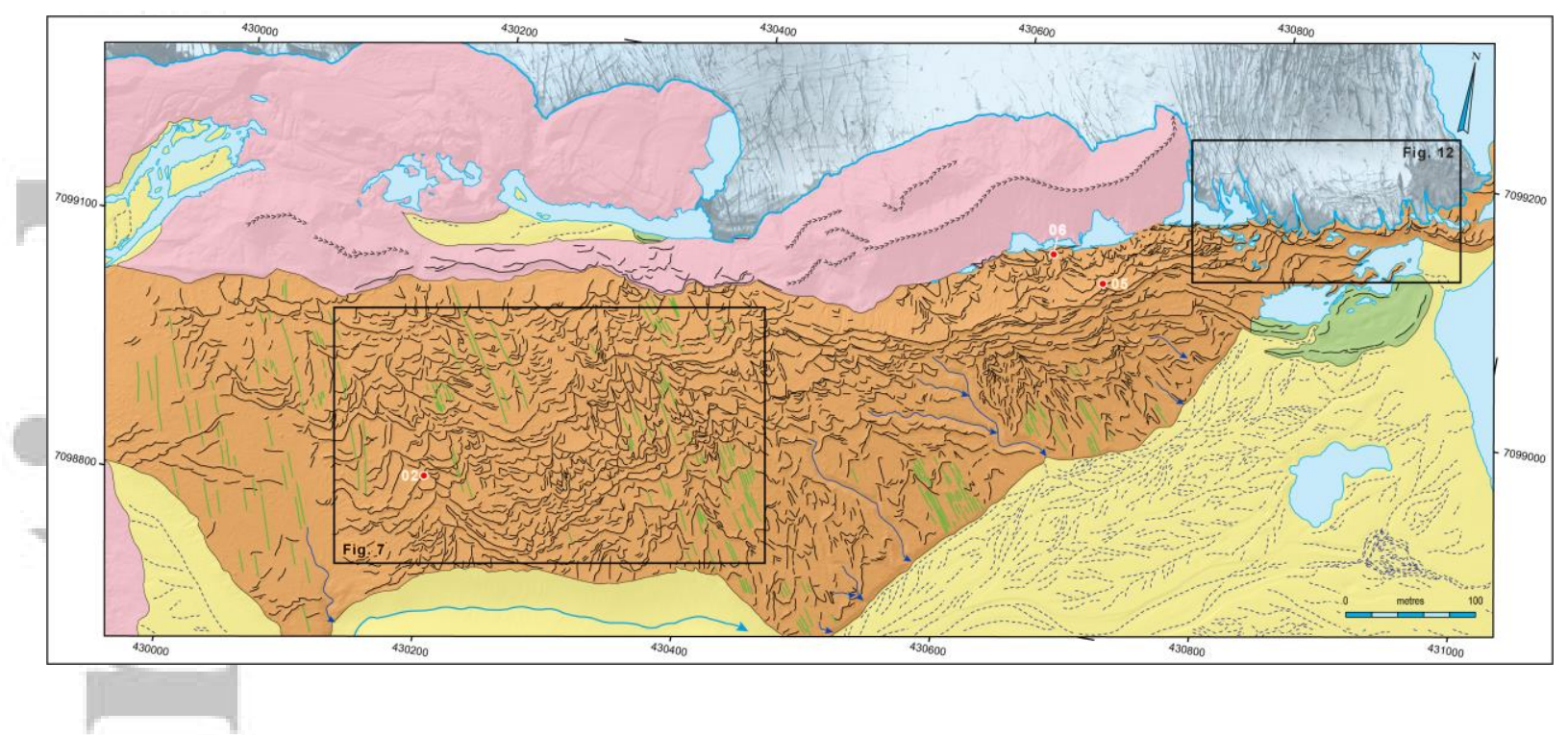

Fig. 6. Glacial geomorphological and surficial geological map showing the complex moraine sequence at the southern Fjallsjökull margin (see Fig. 5, for location). The mapping is based on interpretation of an orthophoto and a DEM derived from our UAV survey in May 2019. The locations of the moraine exposures described in the text are indicated by the numbered red dots. For key, see Fig. 3.

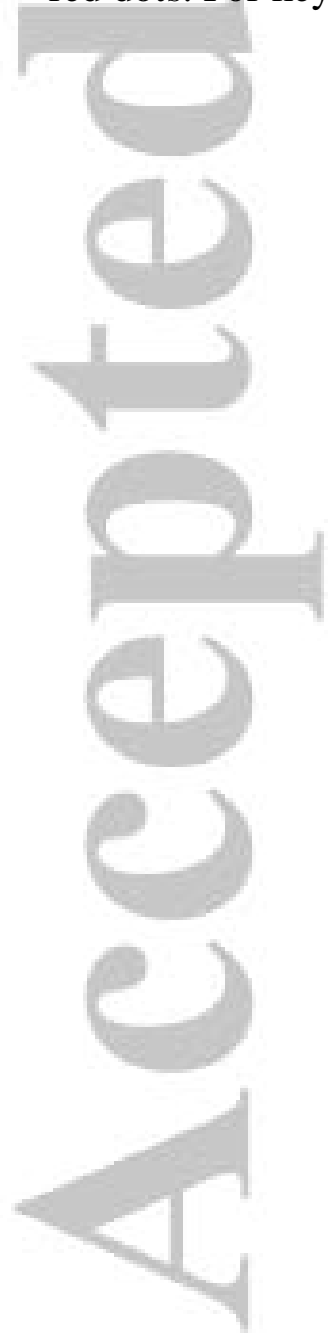

This article is protected by copyright. All rights reserved. 


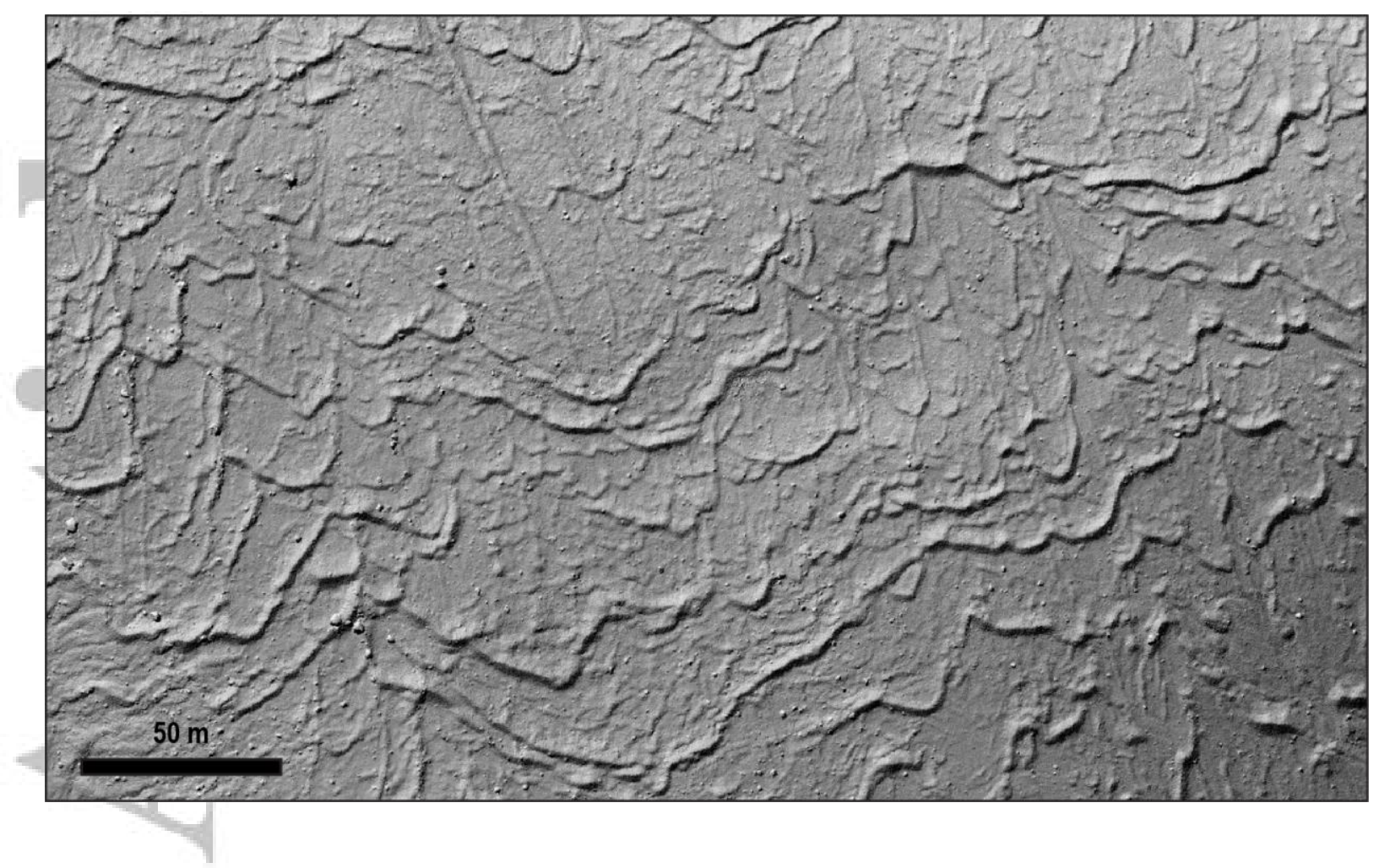

Fig. 7. Hillshade relief model extract showing an area of complex crenulated or sawtooth moraines near the southern Fjallsjökull margin. Note the long limbs of some moraines, which resemble the arms of hairpins. Also note the flutings, which lie the moraines but terminate at different moraines. The hillshade was produced from the 2019 UAV-derived DEM. For location, see Fig. 6.

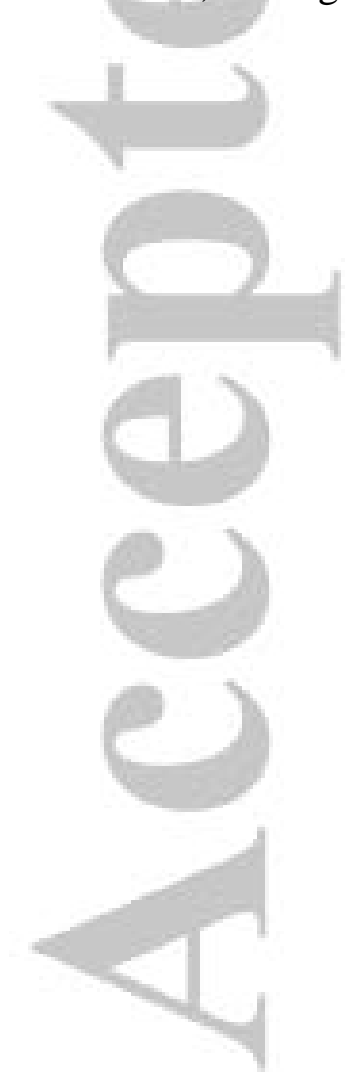

This article is protected by copyright. All rights reserved. 

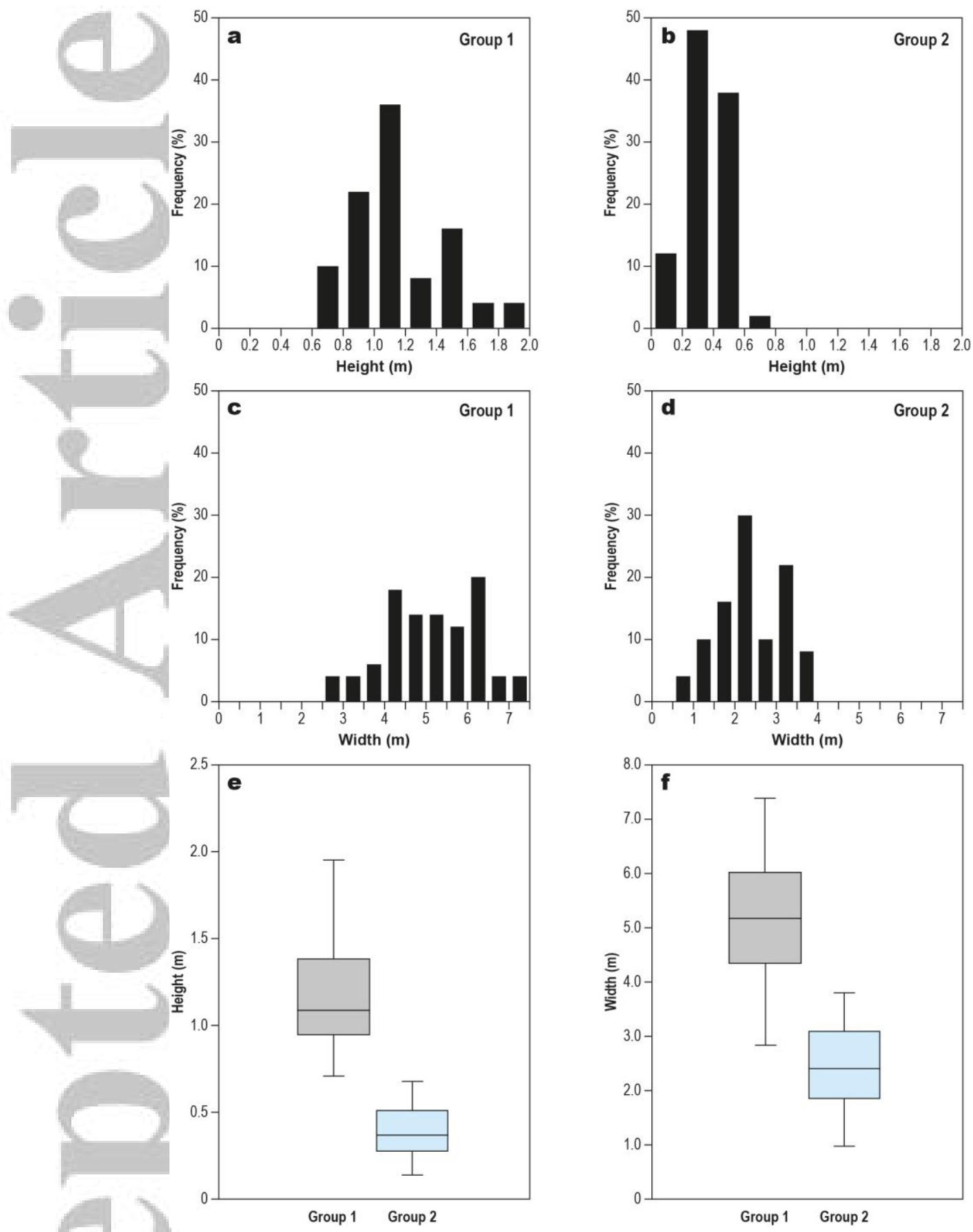

Fig. 8. Morphometric analyses of minor moraines at the southern Fjallsjökull margin. Group 1 consists of moraines that are identifiable and mappable on the coarse imagery $(>0.5 \mathrm{~m}$ per pixel); Group 2 consists of moraines that are only identifiable and mappable on our UAVcaptured imagery. Box-and-whisker plots show the 25th and 75th percentiles (boxes), and the 5th and 95th percentiles (whisker ends). The mean (horizontal line) is also shown. The heights and widths of the moraines were extracted from the 2019 UAV-derived DEM in ArcGIS. 


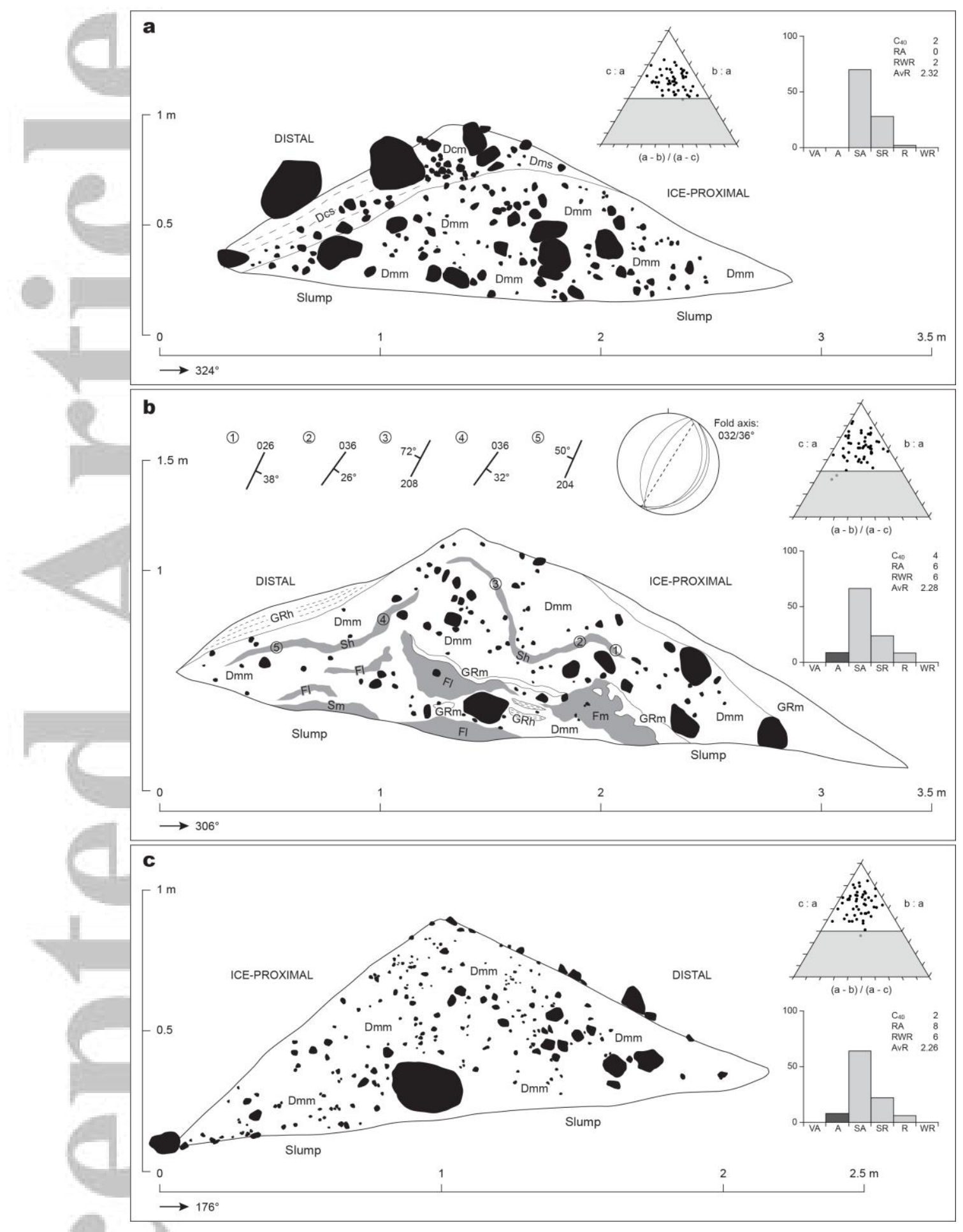

Fig. 9. Logs of the exposure through moraines (a) FJA-02, (b) FJA-05, and (c) FJA-06. The ternary diagrams and frequency distribution plots show the results of clast shape and roundness analyses conducted on clasts from the Dmm units in each moraine. Measurements of the fold axis in FJA-05 (b) are plotted in an equal-area Schmidt net (lower hemisphere). Solid lines represent original measurements; the dashed line, the reconstructed fold axis that strikes NE $\left(032^{\circ}\right)$. For key see Fig. 4; for location, see Fig. 6. 

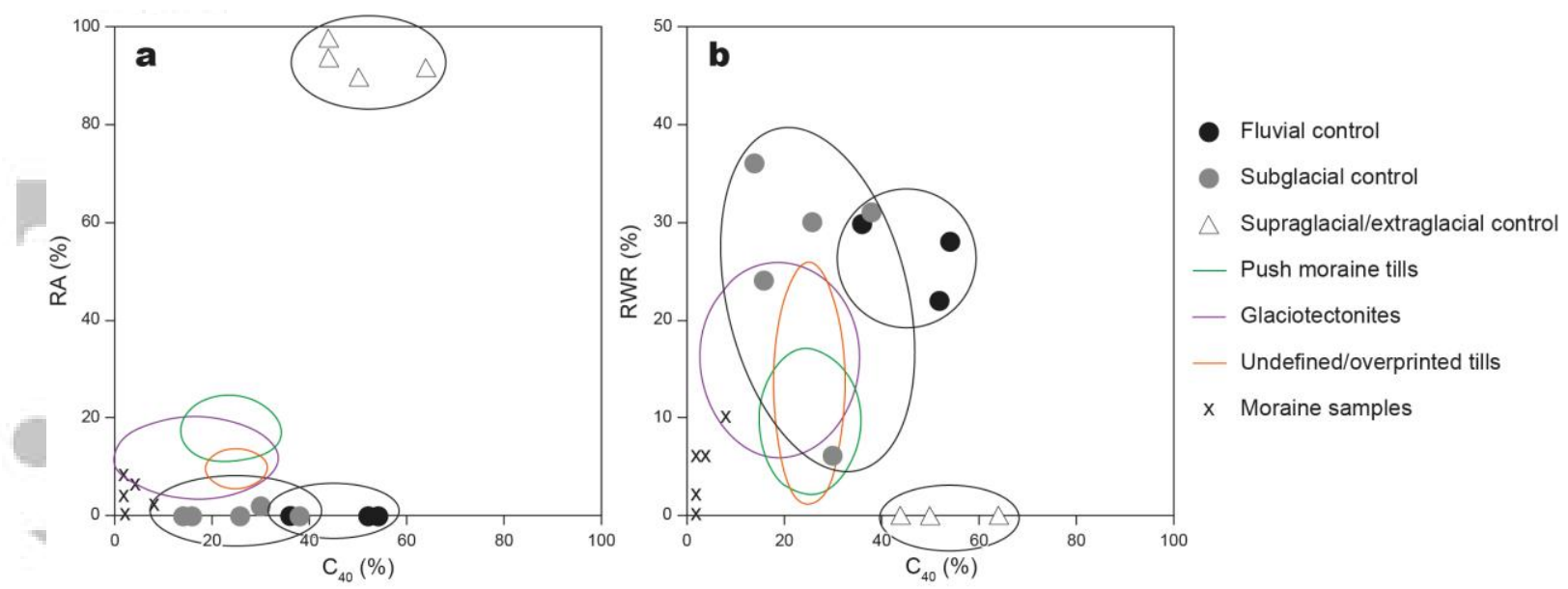

Fig. 10. Covariance plots displaying (a) the RA-index plotted against the $\mathrm{C}_{40}$-index and (b) the RWR-index plotted against the $\mathrm{C}_{40}$-index for the moraine samples and various control samples. The fluvial, subglacial and supraglacial/extraglacial control samples are from Fláajökull, while the push moraine till, glaciotectonite and undefined/overprinted till envelopes are defined based on samples from various Icelandic glaciers (see Evans et al., 2018a). The samples from the moraines indicate they contain subglacially-transported material. 


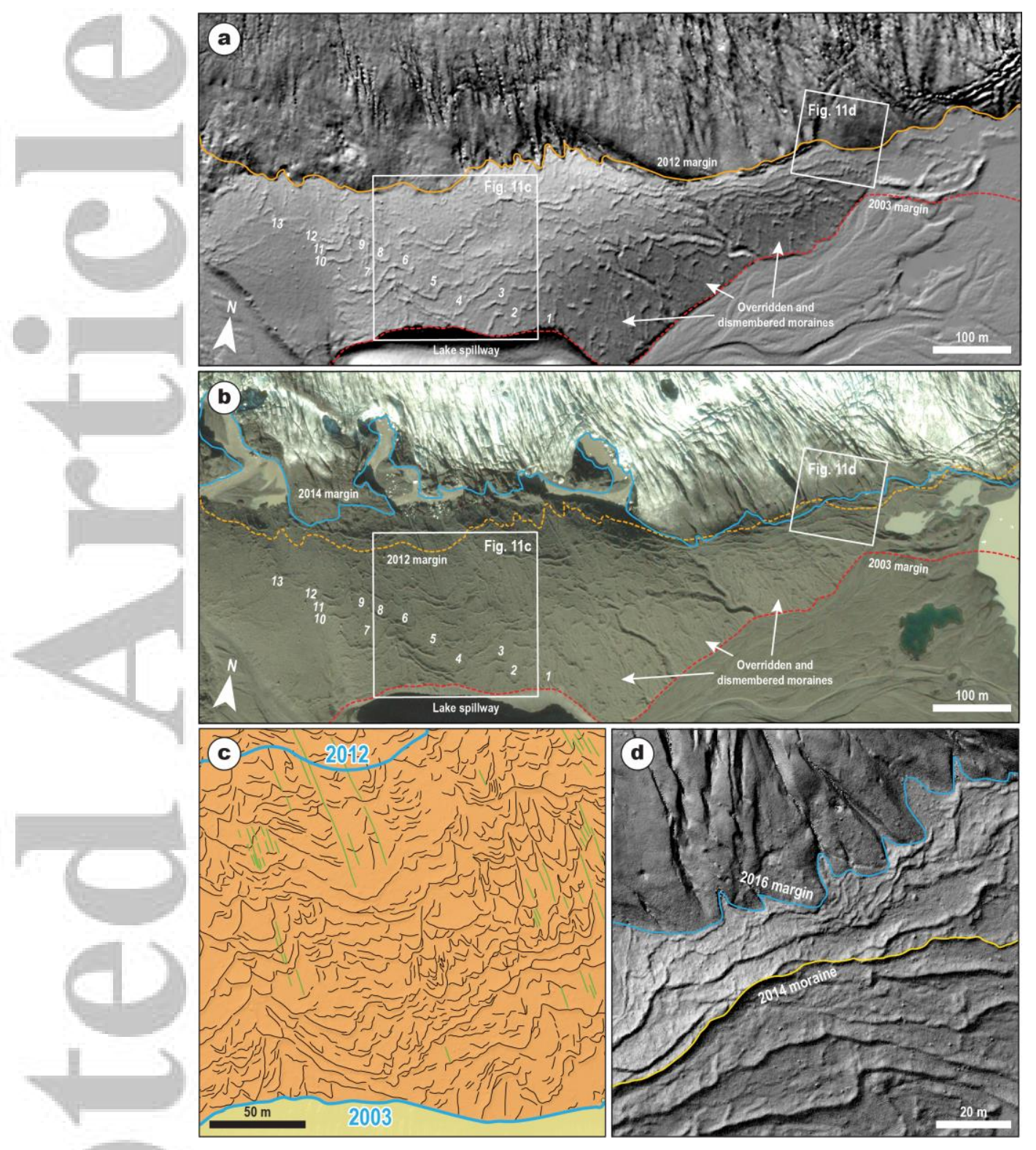

Fig. 11. Imagery and mapping extracts illustrating the relative age of the minor moraines at the southern Fjallsjökull and their formation frequency: (a) Hillshade relief model from the 2012 LiDAR data showing moraines formed between the 2003 (red dashed line) and 2012 (orange line) ice-marginal positions; (b) pan-sharpened, multi-spectral satellite imagery from 2014; (c) extract of the geomorphological mapping (based on the UAV-derived imagery) showing moraines between the 2003 and 2012 ice-marginal positions; and (d) hillshade relief model based on the 2016 UAV imagery, showing the formation of multiple (sub-annual) moraines between 2014 and 2016. Numbers in (a) and (b) indicate prominent moraine ridges in the western - central part of the moraine field that can be identified from the coarser imagery (LiDAR, satellite image). Note that the number of these prominent ridges (13) exceeds the number of years elapsed (9). For detailed description, please see the text. 


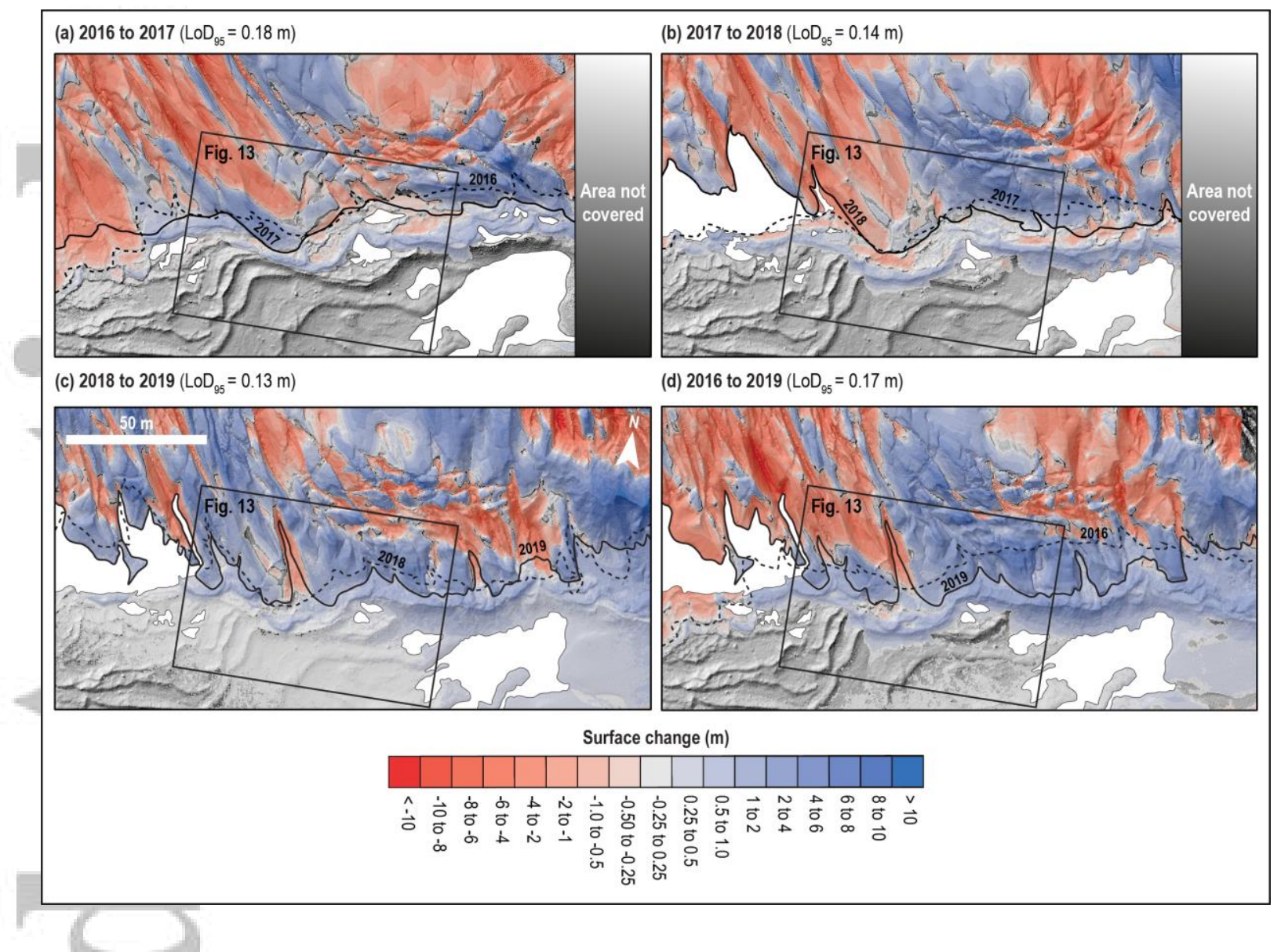

Fig. 12. Thresholded DEMs of Difference (DoDs) showing and quantifying the localised readvance along the eastern part of the southern Fjallsjökull margin. Red areas indicate areas of elevation decrease and blue areas indicate areas of elevation increase. Note the construction of moraine ridges along the ice margin, captured in blue on the DoDs. Ice margin positions are shown by the numbered black lines; white polygons mask water bodies. The DoDs were produced from our dataset of UAV-derived DEMs using the Geomorphic Change Detection (GCD) plugin for ArcGIS (Wheaton et al., 2010). Minimum levels of detection (95\% confidence interval; $\mathrm{LoD}_{95}$ ) were applied to the DoDs, with calculations following Brasington et al. (2003). For further details on the methods, see Supporting Information. For location, see Fig. 6. 


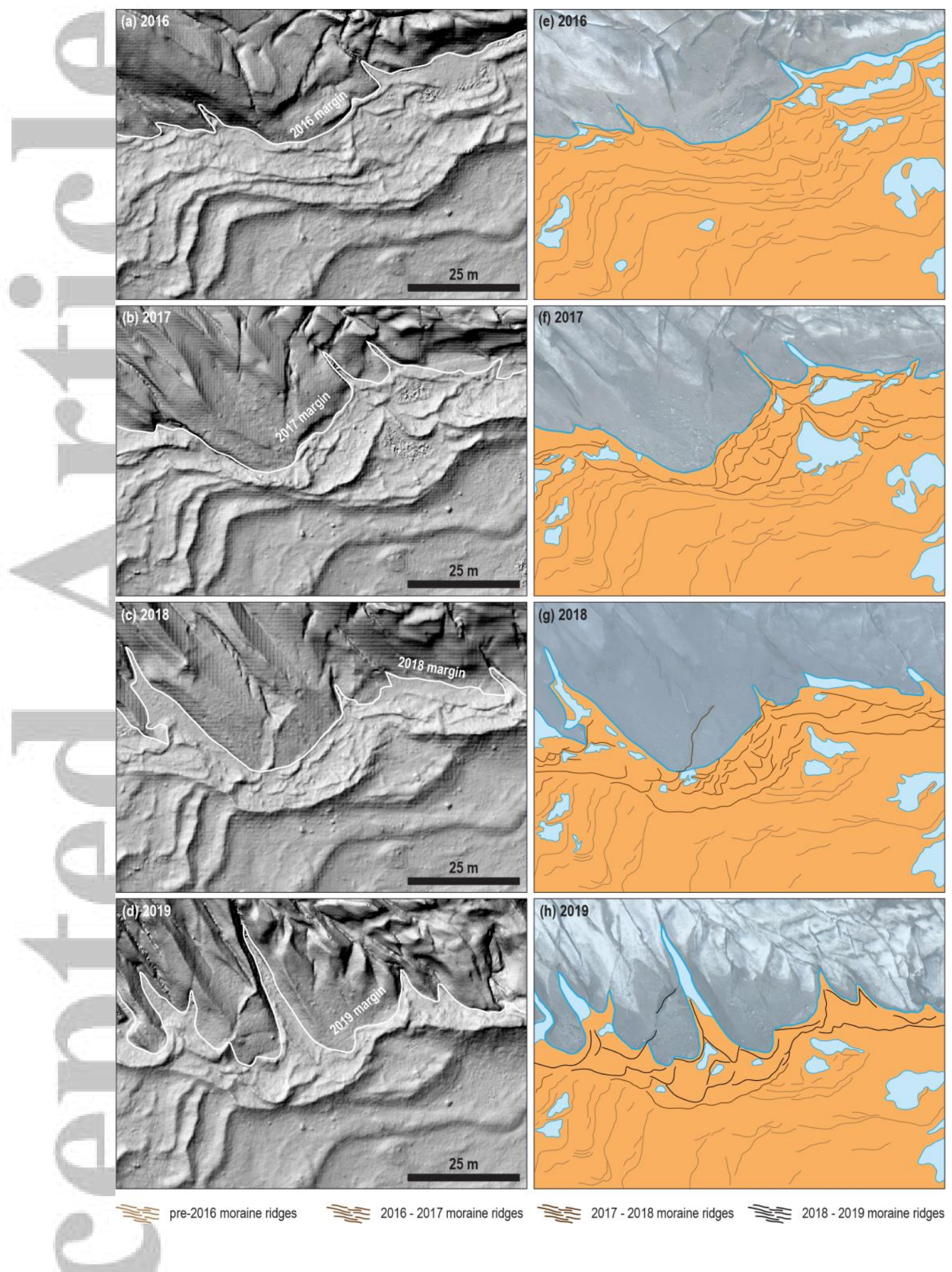

Fig. 13. UAV-derived hillshade relief models (a-d) and accompanying geomorphological map extracts (e-f) that illustrate the construction multiple moraines (i.e. sub-annual moraines) in three consecutive years (2016-2017, 2017-2018, 2018-2019). Re-advances during this period almost entirely obliterated moraines formed in the previous year; the outermost moraine(s) are locally superimposed (b, d) or bulldozed into larger ridges (c). 

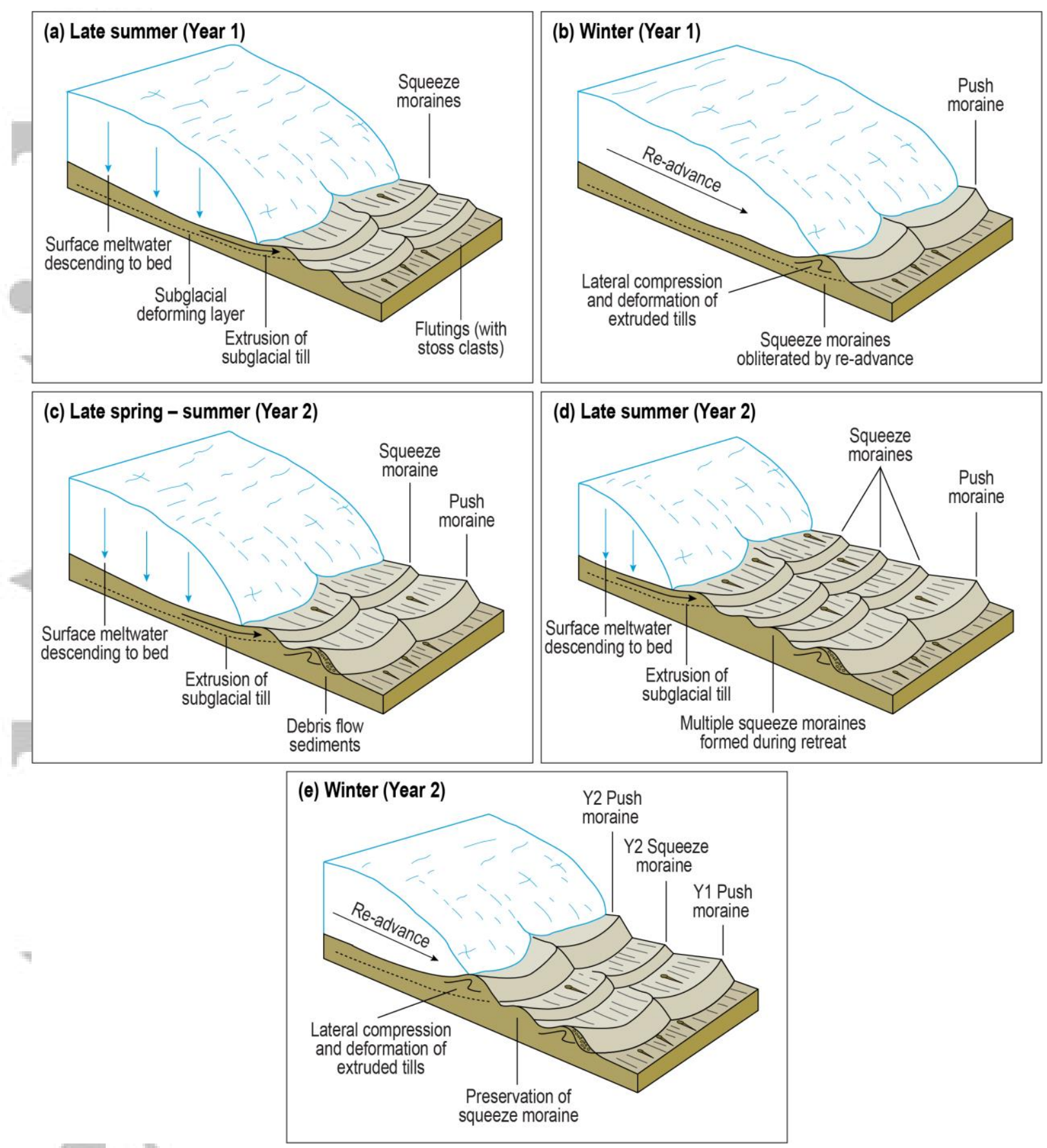

Fig. 14. Simplified conceptual model for the formation of sub-annual moraines at Fjallsjökull, involving melt-driven ice-marginal squeezing of subglacial traction tills and pushing during winter re-advances. Developed from Price (1970). For detailed description, please see the text. 


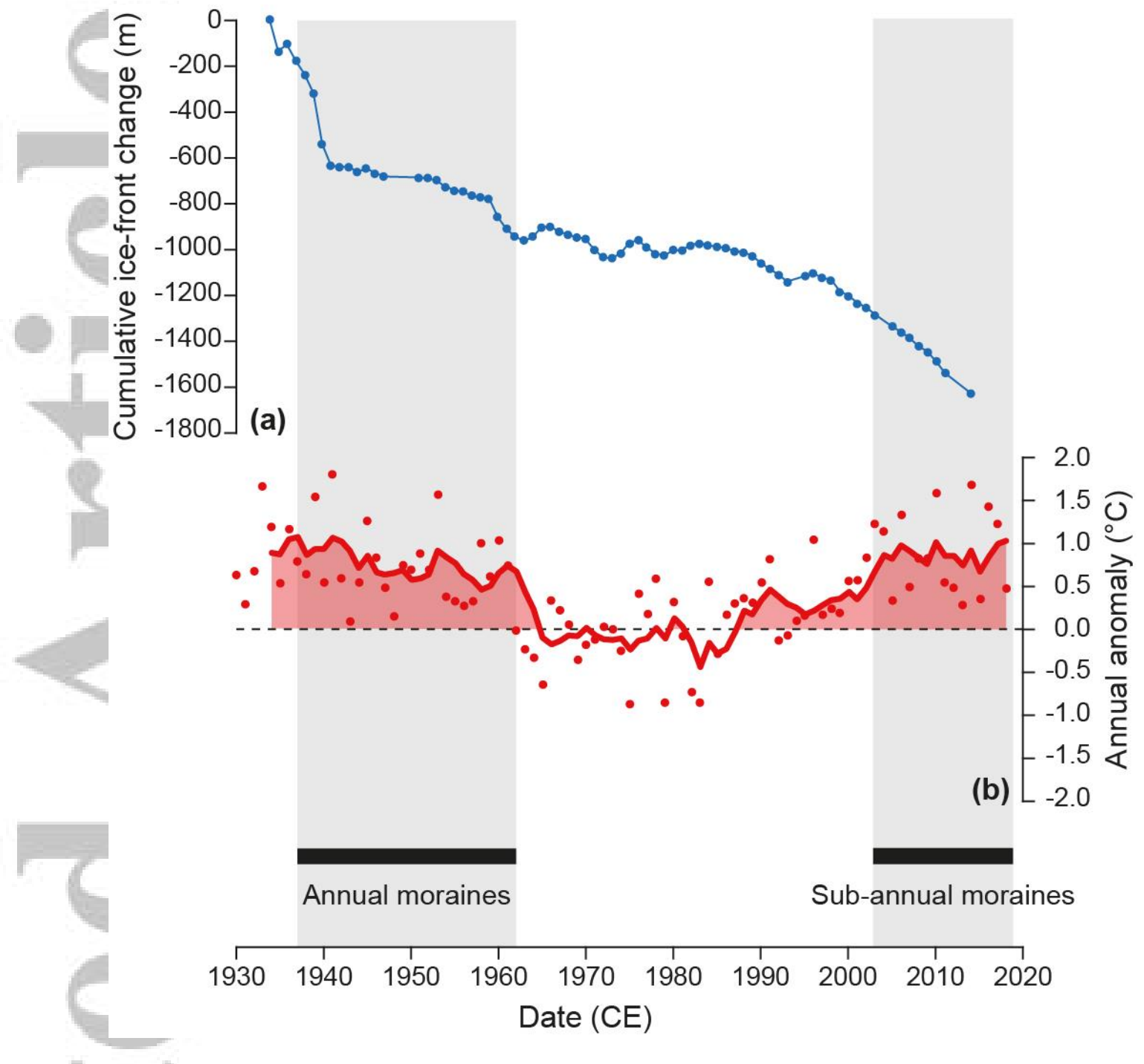

Fig. 15. Comparison between periods of known (sub-)annual moraine formation at Fjallsjökull (solid black lines and grey shading) and (a) ice-front and (b) air temperature fluctuations. The solid lines in (b) shows the 5-year moving average. The air temperature data (b) are from Fagurhólsmýri, the nearest long-term weather station to Fjallsjökull (Veðurstofa Íslands; station no. 745). 